\title{
Seismicity clusters in Central Chile: investigating the role of repeating earthquakes and swarms in a subduction region
}

\author{
Carla Valenzuela Malebran ${ }^{1,2}$, Simone Cesca $^{1}$, Sergio Ruiz ${ }^{3}$, Luigi Passarelli ${ }^{4}$, Felipe Leyton ${ }^{5}$, \\ Sebastian Hainzl ${ }^{1,2}$, Bertrand Potin ${ }^{3}$, Torsten Dahm ${ }^{1,2}$
}

${ }^{1}$ GFZ German Research Centre for Geosciences, Potsdam, Germany.

${ }^{2}$ Universität Potsdam, Potsdam, Germany.

${ }^{3}$ Geophysics Department, Universidad de Chile, Santiago, Chile.

${ }^{4}$ King Abdullah University of Science and Technology (KAUST), Physical Sciences and Engineering Division (PSE), Thuwal, 23955-6900, Saudi Arabia

${ }^{5}$ National Seismological Center, Universidad de Chile, Santiago, Chile

Corresponding author:

Carla Valenzuela Malebrán

Section 2.1, Physics of Earthquakes and Volcanoes GFZ German Research Centre for Geosciences, Potsdam, Germany.

Helmholtzstr. 7, 14467 Potsdam, Germany

E.mail: carlav@gfz-potsdam.de 


\section{Abstract}

Seismicity along subduction interfaces is usually dominated by large mainshock-aftershocks sequences indicative of a continuum distribution of highly coupled large asperities. In the past decades, however, the increased resolution of seismic catalogues at some subduction zone seems to indicate instead a more complex rheological segmentation of the interface. Large and megathrust earthquake ruptures seem interspersed among regions of low seismic coupling and less stress buildup. In this weaker zones, the strain is primarily released via a combination of moderate size swarmlike seismicity and aseismic slip. Along the Chilean subduction zone, the densification of the seismic network allowed for the identification of localized seismic clusters, some of them appearing in the form of swarms before megathrust earthquakes. The origin and driving processes of this seismic activity have not yet been identified. In this study, we follow a systematic approach to characterize the seismicity at two persistent clusters in Central Chile, one located offshore Navidad and one inland, at $\sim 40 \mathrm{~km}$ depth beneath Vichuquén, which occurred throughout $\sim 20$ years. We investigated these clusters, by deriving high resolution hypocentral locations and moment tensors and performing a detailed analysis of spatio-temporal patterns, magnitude, and inter-event time distributions of the clustered earthquakes. Both clusters are characterized by weak to moderate seismicity (below $\mathrm{M}_{\mathrm{W}} 6$ ) and stand out as clear seismicity rate and Benioff strain anomalies. At the Navidad cluster, seismicity occurs in the form of swarms, with a characteristic duration of 2-7 days and location and thrust mechanisms compatible with activity on the slab interface. Conversely, we find at Vichuquén activity dominated by thrust earthquakes occurring as repeaters on the slab interface, with a slip rate of approximately $\sim 5.0 \mathrm{em} / \mathrm{yr}$. We attribute these clusters to local features of the subducting plate: the Navidad swarms are likely driven by repeated high pore pressure transients along a pre-fractured patch of the slab, while the seismicity at the Vichuquén cluster is interpreted as the result of a subducting seamount. Both clusters have been active before and after the $\mathrm{M}_{\mathrm{W}} 8.8$ Maule earthquake and persisted afterwards with the seismicity decay following the Omori law. These interactions are especially evident for the Vichuquén cluster, where the seismicity rate increased considerably after the Maule earthquake and continues to be an area of clearly elevated seismicity rate compared to its surroundings.

Key words: Subduction zone processes, Waveform inversion, Time-series analysis, Spatial analysis, Persistence, memory, correlations, clustering. 


\section{Introduction}

Chile is a very seismically active country due to the subduction of the Nazca plate beneath the South America plate at a rate of approximately $6.8 \mathrm{~cm} / \mathrm{yr}$ (Métois et al. 2012; Vigny et al. 2009). The central part of the Chilean subduction segment, between latitudes $32^{\circ} \mathrm{S}$ and $36^{\circ} \mathrm{S}$, has repeatedly experienced mega-thrust earthquakes over the centuries. Large earthquakes $\left(\mathrm{M}_{\mathrm{W}} \sim 8\right)$ were reported in the years $1575,1647,1730,1822,1906,1965,1971$, and 1985; of which the 1730 is the largest one, with a magnitude around 9.0 (Fig. 1; see also, Comte et al. 1986; Udías et al. 2012; Roth et al. 2017; Ruiz \& Madariaga 2018). The last large earthquakes to rupture in this segment were the $1985 \mathrm{M}_{\mathrm{W}} 8$ Valparaíso earthquake and the $2010 \mathrm{M}_{\mathrm{W}} 8.8$ Maule earthquake, followed by the $2010 \mathrm{M}_{\mathrm{W}} 6.9$ and $\mathrm{M}_{\mathrm{W}}$ 7.0 Pichilemu earthquake doublet, see Fig. 1 (Madariaga et al. 2010; Ruiz et al. 2012; Ruiz J. et al. 2014; Farías et al. 2011; Lange et al. 2012). The two Pichilemu earthquakes that occurred $\sim 15$ minutes apart and 12 days after the $\mathrm{M}_{\mathrm{W}} 8.8$ Maule earthquake have been likely triggered by static stress changes imparted by the megathrust event (Farías et al. 2011; Ruiz J. et al. 2014). This shallow intra-plate doublet ruptured along a splay fault system with a normal faulting mechanism, oblique striking with respect to the plate margin.

Besides large, destructive earthquakes, central Chile has also been characterized in the last decades by repeated localized seismicity clusters. Single occurrences and long-lasting sequences in Chile have been studied in detail by Gardi et al. (2006), Holtkamp et al. (2011) and Poli et al. (2017). However, the behavior of clusters has been rarely analyzed over long periods and large areas (Poli et al. 2017). For some of the seismogenic volumes with spatially clustered seismicity, the temporal evolution of seismicity is characterized by the repeated observation of seismicity burst episodes in the form of seismic swarms, persisting over one to a few days. In other cases, the temporal evolution persists over longer times and in the same area producing so-called repeating earthquakes (Kato \& Nakagawa 2014; Poli et al. 2017). 
A seismic swarm is usually characterized by an increment in the seismicity rate localized in space and time, lacking a clear mainshock at the beginning of the sequence and departing from the typical time decay of the aftershock rate (Hill 1977; Sykes 1970). The duration of swarm activity does not scale with cumulative seismic moment released (Passarelli et al. 2018) nor does the seismicity rate follow any empirical scaling with time (Hainzl 2003). Namely, many seismic swarms have a less abrupt increase in seismicity rate followed by a slower fading out phase with respect to the Omoritype time decay (Omori 1894). Furthermore, swarms tend to have many earthquakes of comparably larger magnitudes, and thus do not follow Bath's relation on magnitude intervals (Båth 1965). Seismic swarms are often interpreted as a consequence of fluid redistribution in the crust, which can reduce the effective normal stress and thus the friction along pre-existing critically stressed faults (Kisslinger 1975; Noir et al. 1997; Yamashita 1999). Other studies show that the occurrence of swarms can be driven by slow slip events, as indicated by several cases of geodetically observed episodes of transient deformation accompanied by swarm activity (Crescentini et al. 1999; Lohman \& McGuire 2007; Ozawa et al. 2007; Vallée et al. 2013; Vidale et al. 2011).

Along the Chilean subduction segment, seismic swarms were observed prior to large earthquakes, such as those that occurred before the Valparaíso earthquakes of 1985 and 2017 (Comte et al. 1986; Ruiz et al. 2017), the 2010 Maule earthquake (Madariaga et al. 2010) and the 2014 Iquique earthquake (Ruiz S. et al. 2014; Kato \& Nakagawa 2014; Meng et al. 2015; Cesca et al. 2016), and were hypothesized as possible precursors. However, in other cases swarm activity did not develop into major earthquakes, as e.g. in the case of the Copiapó seismic swarms in 1973 and 2006 (Comte et al. 2007; Holtkamp et al. 2011).

A combination of seismic swarms and aseismic slip release sometimes precedes the occurrence of large damaging megathrust earthquakes, which is interpreted as static stress loading in the megathrust formation (Kato \& Nakagawa 2014; Kato et al. 2016). On the contrary, the subduction 
segments hosting repeating swarm-like activities without a main earthquake seem to indicate areas previously unruptured by large megathrust earthquakes (Holtkamp \& Brudzinski 2011). As suggested by Holtkamp and Brudzinski (2014), due to a more ductile fault rheology, these areas are less prone to accumulate tectonic elastic stresses in the interseismic period and appear to act as a barrier against the rupture propagation of large events. Despite advances in understanding the occurrence of seismic swarms and their triggering mechanism, their relative importance in releasing tectonic strain remains largely unknown (Passarelli et al. 2018).

In addition to earthquake swarms, the detection of repeaters helps to improve the understanding of the deformation process, because their presence implies aseismic slip. Interplate slow slip is known to play an important role in the fault deformation and earthquake cycle along subduction zone (e.g., Bürgmann 2018; Obara \& Kato 2016).

Repeating earthquakes are defined as families of earthquakes characterized by nearly identical waveforms, denoting similar source locations and mechanisms. Igarashi et al. (2003) showed that the observation of highly similar full waveforms in high-frequency recordings at different stations for two or more repeaters implies the proximity of their hypocenters even below $1 \mathrm{~km}$ and almost identical focal mechanisms.

They are typically interpreted as the result of multiple rupture of similar sized asperities; their loading mechanism is usually attributed to underlying aseismic slip (i.e. creeping, slow-slip event or afterslip) (Schaff et al. 1998; Nadeau \& McEvilly 2004; Uchida et al. 2003, 2015; Chen et al. 2010). Therefore the detection of repeaters can help to track the fault creep (Uchida 2019) and provide insight about the mechanical properties of the seismogenic volume, such as slip rate at the plate boundary and presence of aseismic strain release processes (Ellsworth 1995; Nadeau \& McEvilly 1999; Igarashi et al. 2003; Uchida et al. 2003). 
Repeating earthquakes have been identified in several tectonic settings. In Chile, families of repeating earthquakes have been identified in the region of Iquique, northern Chile, before and after the $2014 \mathrm{M}_{\mathrm{W}} 8.2$ Iquique earthquake (Kato \& Nakagawa 2014; Kato et al. 2016; Soto et al. 2019).

In this work we investigate 20 years of seismic data along the Central Chile subduction region, in order to detect and characterize seismic cluster activities over a large time period, before and after one of the largest subduction earthquakes $\left(2010 \mathrm{M}_{\mathrm{W}} 8.8\right.$ Maule) and important local earthquakes in the study region (such as the $2010 \mathrm{M}_{\mathrm{W}} 6.9$ and 7.0 Pichilemu doublet). A careful investigation of the clustered seismicity over almost two decades enables us to infer information/about seismotectonic processes at the Chilean converging margin and to establish a precedent for future seismic cluster patterns.

\section{Seismicity cluster}

We analyze 20 years of seismicity data based on the seismic catalogue of the National Seismological Center (CSN) of the Universidad de Chile from January 1, 2000, to January 1, 2020 (http://www.sismologia.cl/, last accessed 15.3.2020). We focus on the region spanning from $33^{\circ}-$ $36^{\circ} \mathrm{S}$ and $71-73.5^{\circ} \mathrm{W}$ and consider only events down to a depth of $70 \mathrm{~km}$ that, in this region, reducing the dataset mostly to interplate earthquakes. The configuration and density of the seismic network has changed significantly over time. The substantial increase in the number of seismic stations deployed following the 2010 Maule earthquake (fig. S1) led to an increase in the location accuracy (Barrientos 2018). We estimate an overall magnitude of completeness $\mathrm{Mc}=2.8$ for the entire 2000-2020 period (excluding the period of the 2010 Maule earthquake) by using the Goodness-of-Fit method (Wiemer \& Wyss 2000; fig. S2). 
The cumulative distribution of seismicity as a function of latitude (Fig. 2) shows two clear peaks of higher seismicity at latitudes $\sim 34.0^{\circ} \mathrm{S}$ and $\sim 34.8^{\circ} \mathrm{S}$ (Figs. $2 \mathrm{a}$ and $2 \mathrm{~b}$ ), which are both recognized for the whole time period (i.e. since 2000) as well in the most recent catalogue after the Maule earthquake (from 1.1.2012, colored dots in Figs. 1 and 2a).

\subsection{Spatial distribution of seismicity clusters}

We combine different methods to investigate and compare seismicity patterns of different clusters. For the detection of spatial earthquake clusters, we use a density-based clustering algorithm (Cesca et al. 2014; Maghsoudi et al. 2013; Cesca 2020). The method scans the hypocentral distribution of the CSN catalogue, searching for regions with high earthquake density to detect seismicity clústers: the spatial boundaries of each cluster are defined according to a predefined earthquake density threshold. Isolated earthquakes and those located in regions of low seismicity remain non-clustered. The definition of clustering parameters has been chosen with the objective to simultaneously resolve a limited number of clusters and reduce as much as possible the amount of unclustered events (Cesca 2020).

For the spatial clustering, we use the spatial distance between hypocenters as a metric. We originally consider the 2012-2020 seismic catalogue, given the hypocentral locations are more accurate in this time period, occurring within the region bounded by $33.0^{\circ}-36.0^{\circ} \mathrm{S} 71.0^{\circ}-73.5^{\circ} \mathrm{W}$, and depths shallower than $70 \mathrm{~km}$, we only consider events with magnitude $\mathrm{M}_{\mathrm{L}}>2.8(\mathrm{Mc})$. The density based clustering is tuned by the choice of two parameters: $\varepsilon$ and Nmin. $\varepsilon$ defines the maximal normalized hypocentral distance to search for neighbor events, while Nmin defines the minimum number of neighbor events to define a cluster; a cluster is formed around an event $\mathrm{i}$, whenever there are at least Nmin other events located within a distance $\varepsilon$. Here, we choose the clustering parameters $\varepsilon=0.01$ and $\mathrm{Nmin}=55$ (equivalent to $2 \%$ of the catalogue size), thus 
clusters: the first one (224 events) is located at about $33.8-34.2^{\circ} \mathrm{S}$ and $72.1-72.6^{\circ} \mathrm{W}$, off the coast of the town of Navidad (from now on Navidad cluster, blue circles in Fig. 3), while the second one (271 events), is located onshore at $34.5-34.9^{\circ} \mathrm{S}$ and $71.5-72.0^{\circ} \mathrm{W}$, roughly beneath the town of Vichuquén (Vichuquén cluster, red circles in Fig. 3); a third cluster, at the Northern boundary of the study region, corresponds to the aftershock sequence of the 2017 Valparaíso earthquake (Nealy et al. 2017; Ruiz et al. 2017) and it is not investigated here. We then search for earthquakes located in the same volume for previous times period (since 1.1.2000): as a result, the seismicity clusters grow to a population of 578 (Navidad cluster) and 830 (Vichuquén cluster), respectively. The two clusters (Fig. 3a, Table 1) are located approximately at the northern and southern edges of the Pichilemu $2010 \mathrm{M}_{\mathrm{W}} 6.9$ and 7.0 earthquake ruptures and correspond to the two high-density peaks identified in Fig. 2. However, their average depths suggest they are located at the slab interface, whereas the Pichilemu doublet ruptured normal faults at shallower depth within the overriding plate. The temporal evolution of the clustered seismicity (Fig. 3b) shows that magnitudes are moderate, below $\mathrm{M}_{\mathrm{L}}$ 6.0, and substantial differences among the temporal evolution of seismicity, with steady seismicity at Vichuquén and repeated bursts of activity at Navidad (these features are investigated in detail in the next section).

We analyze the spatial distribution of seismicity in a broader study region, including both clusters, mapping the epicenter density and computing statistical seismicity parameters (Fig. 4). This analysis is performed only for the 2012-2020 catalogue. We discretize the study region using a regular grid of $0.05^{\circ} \times 0.05^{\circ}$ spacing and then consider cylindrical cells of $20 \mathrm{~km}$ radius and $70 \mathrm{~km}$ height, centered at each grid point. For each cell, we calculate the event density and the cumulative Benioff strain. Furthermore, $b$-value and the coefficient of variation for inter-event times are computed for those cells with a minimum of 50 earthquakes. Perturbations of the minimum numbers of earthquakes and radius do not significantly alter the results. Mapping the seismicity density (Fig. 4a) first highlights the increased number of earthquakes within the two clusters, 
corroborating their identification by the density-based clustering algorithm. Seismic clusters can be also well depicted based on the cumulative Benioff strain (Fig. 4b), which is defined as the square root of the radiated seismic energy (SE) and proportional to the elastic strain released by an earthquake (Benioff 1951). To calculate the SE from the earthquake magnitudes $\mathrm{M}_{\mathrm{L}}$, we used the relationship: $\log (S E)=3 / 2 M_{L}+4.8$ (Gutenberg \& Richter, 1956). $\mathrm{M}_{\mathrm{L}}$ is the local magnitude reported in the CSN catalogue. Given the log-linear scaling between SE and magnitude and the square root operation, a Benioff strain map helps to empathize more the energy released by small earthquakes with respect to the large ones than a simple cumulative seismic moment map.

The spatial fit of the empirical magnitude-frequency distributions to the Gutenberg-Richter model returns a regional, average value of $0.76 \pm 0.01$, which is compatible with a subduction environment (Schorlemmer et al. 2005). Comparably low b-values are obtained for the two clusters (i.e. using only events coming from the clustering algorithms), equal to $0.71 \pm 0.04$ at Navidad and $0.75 \pm 0.04$ at Vichuquén (Fig. 4c). In order to investigate temporal seismicity rate variations, we study the distribution of inter-event times, i.e. the time between two consecutive earthquakes in the catalogue. A widely used measure of the variability of inter-event time distribution is the coefficient of variation $C V=\delta / \mu$, where $\delta$ is standard deviation and $\mu$ the sample mean value. A random Poisson occurrence leads to a value of $C V=1$ and a quasi-periodic occurrence of events to a $C V$ below 1 . $C V>1$ is typically found for temporal clustering, which means that there is a tendency for events to be grouped in a short time (Kagan \& Jackson 1991; Zöller et al. 2006; Maghsoudi et al. 2013; Passarelli et al. 2015), For this analysis, we only used events with magnitudes larger or equal than the magnitude of completeness Mc (Fig. 4d). We obtained a high $C V$ value at the Navidad offshore cluster $(C Y=2.0 \pm 0.3)$, which indicates temporal clustering, a pattern typical for seismic swarms. In the Vichuquén onshore cluster zone, a $C V$ value close to $1(C V=1.1 \pm 0.1)$, which indicates a random temporal occurrence of earthquakes. 


\subsection{Temporal evolution of the cluster activity}

In order to study the temporal evolution of the cluster activity, we augment the dataset, considering events over a longer period, i.e. between 2000 and 2020. A visual inspection of the temporal evolution of seismicity of the Navidad and Vichuquén clusters (Figs. 2 and 5) shows that both clusters were active well before the Maule earthquake (27 February 2010). At the Vichuquén cluster the seismicity appears to be stable over time, while at the Navidad cluster it is characterized by recurrent, short-lasting peaks in the seismicity rate (Fig. 5). In order to investigate objectively the fluctuation of the seismicity rate and isolate periods of higher seismic activity, we apply the $\beta-$ statistics (Matthews \& Reasenberg 1988).

The $\beta$-statistics calculated in time windows represents the standardized distribution of the number of events with respect to the long-term background seismicity rate and is defined as:

$$
\beta=\left(n(t, \Delta t)-n_{e}(t, \Delta t)\right) / \sigma(t, \Delta t)
$$

where $n(t, \Delta t)$ is the number of observed events in $(t, t+\Delta t)$ and $n_{e}(t, \Delta t)$ and $\sigma(t, \Delta t)$ are the average and standard deviation of the expected events given the observed background seismicity rate $r$ (Matthews \& Reasenberg 1988). As background model, we use a superposition of constant background seismicity rate and Omori decay following the Maule mainshock with parameters fit by the maximum likelihood method: $R(t)=m u+K\left(c+t-t_{\text {Maule }}\right) H\left(t-t_{\text {Maule }}\right)$ with $\mathrm{H}$ being the Heaviside function (Fig. 5). We calculate the $\beta$-statistics for both Navidad and Vichuquén regions as reported by the black lines in Figs. $5 \mathrm{~b}$ and $5 \mathrm{c}$. The numerical values of the $\beta$-statistics represent how many standard deviation $(\sigma)$ the observed rate is higher than the background rate $\left(n_{e}(t, \Delta t)\right), t$ is the time and $\Delta t$ is the time sampling interval. The analysis of $\beta$-statistics for the Navidad cluster shows periods of increase of $\beta$-statistics values $(>5)$ corresponding to significant bursts in the seismicity rate (Fig. 5b): At the Navidad cluster we identify a total of 10 clusters between 2000 and 2020 (Fig. 
5b, Tab. 2) that corresponds to periods of increased seismicity (Fig. 5b). On the contrary, for the Vichuquén region (Fig. 5c) the algorithm confirms stationary seismicity rate with no clear peaks throughout the studied period, continuous activation without significant subclustering. However, we noticed a clear increase in the seismic rate after Maule earthquake, and in 2019 the observed rate is still higher than the background rate before Maule (Fig. 5a).

Once bursts of activity are detected, we further analyze each of them by applying a skewness analysis of the scalar moment released, in order to classify if they correspond to swarms or to a mainshock-aftershock sequence (Roland \& McGuire, 2009). For this analysis, earthquake local magnitudes are translated in a seismic moment through standard scaling (Hanks \& Kanamori 1979). Seismic swarms differ from typical mainshock-aftershock sequences by their seismicity patterns in time and magnitude: largest events tend to occur later in the swarm sequence and elevated seismicity is more prolonged in time (Roland \& McGuire 2009; Passarelli et al. 2018). We use the skewness of the moment release $\left(M_{0}\right)$ history:

$$
F(t)=\int_{t_{0}}^{t} M_{0} d t
$$

to quantify the difference between mainshock-aftershocks and swarm-like behavior. A large positive value of the skewness of $F(t)$ is typical for aftershock sequences (skewness $>>8$ ), while a low or even negative value is typical for swarms(Roland \& McGuire 2009; Chen \& Shearer 2011). For the swarm episodes at the Navidad cluster, we find skewness values between -9 and 7 (Table 2), compatible with values obtained for other swarms elsewhere (Roland \& McGuire 2009; Chen \& Shearer 2011; Passarelli et al. 2018). 


\section{Analysis of clustered seismicity}

\subsection{Hypocentral locations}

Original locations by the CSN, which are based on a 1D velocity model, were first improved by considering a regional 3D model (see fig. S5). While the $1 \mathrm{D}$ velocity model is used for routine location procedure at CSN, the 3D model was developed using P and S picks by the CSN catalogue within a Bayesian approach (Potin 2016) and adopted in previous studies (e.g. Ammirati et al. 2019, Ruiz et al. 2019). Then, we further relocated a subset of events in both clusters during the time period 2012-2020 using a double-difference algorithm by the HypoDD program (Waldhauser \& Ellsworth 2000). For the relocation we relied on 18012 P picks and 13988 S picks for Navidad cluster, and for Vichuquen cluster we relied on $12946 \mathrm{P}$ picks and $11060 \mathrm{~S}$ picks as well as waveform cross-correlation, using more than 40 seismic stations and more than 70000 and 100000 differential times for the Navidad and Vichuquén clusters respectively, substantially reducing time residuals. In both clusters, seismicity is relocated close to the subduction interface. The Navidad cluster is located at $\sim 20 \mathrm{~km}$ depth and the Vichuquén cluster is located at a larger depth of $\sim 40 \mathrm{~km}$. The spatial distribution of locations is in general agreement with the geometry of the slab interface.

\subsection{Moment tensor inversion}

We combine moment tensor (MT) inversion and waveform similarity analysis to further investigate the source processes at both clusters. We perform the MT inversion only for the largest earthquakes, which are recorded by a sufficient number of regional stations with a good signal-to-noise ratio. We model full waveform displacements and amplitude spectra (Cesca et al. 2010, 2014) and discuss only high-quality solutions as defined in Cesca et al. (2010), with an amplitude spectra L2 norm misfit below 0.5 .

Seismic waveforms retrieved from IRIS and CSN repositories for all stations with epicentral distances below $500 \mathrm{~km}$ are pre-processed, deconvolving the instrument transfer function, 
integrating to displacements, bandpass filtering in the range $0.02-0.08 \mathrm{~Hz}$, applying a temporal tapering to extract full waveforms and down sampling to $2 \mathrm{~Hz}$. To generate synthetic seismograms and spectra, we used a regional 1-D velocity model (CRUST2.0 database, Bassin et al. 2000). As a result of the MT inversion, we obtained both a double couple (DC) and full moment tensor (MT), the centroid location and centroid depth, the scalar moment and its corresponding moment magnitude.

The MT inversion improves through time along with the densification of the seismic network. For example, during 2012 and 2013 only three broadband stations were available and the MT inversion was only possible for events above $\mathrm{M}_{\mathrm{W}}$ 4.0. Conversely, from May 2014 we obtained more stable, higher-quality solutions for the centroid and focal mechanisms for events down to magnitude $\mathrm{M}_{\mathrm{W}}$ 3.8. Given the relatively low magnitude of the target seismicity and the limited data amount, we found that full MT results are not always stable and restrict our discussion only to DC source solutions: we obtain 32 solutions for the Navidad cluster and 17 for the Vichuquén cluster (Fig. 6).

Focal mechanisms at both clusters display generally thrust faulting, as expected in the subduction zone at shallow depth, in general agreement with the few (10) available reference solutions by Global CMT. The distribution of MTs at the Navidad cluster is more heterogeneous, whereas focal mechanisms are very similar at the Vichuquén cluster. The focal mechanism variability at Navidad can be partially explained by the lower MT resolution for offshore locations; however, we also depict clear differences among the focal mechanisms of swarm and inter-swarm events. We use the Kagan angle (Kagan 1991, 1992) as a similarity measure of the focal mechanisms among each group of focal mechanisms solutions (e.g. for different clusters and to compare swarm vs nonswarm events) and we define the median focal mechanism, as the one minimizing the cumulative Kagan angle to the focal mechanisms of each dataset (Tables S2-S3). The median mechanism for swarm events presents higher dip angles compared to the plate interface. The result of the median 
mechanisms for swarm events in 2014 and 2018 seem different from each other (Table S4), which suggests that different swarms activate different fault sections in the plate interface or rather a set of faults. Inter-swarm events have a median mechanism with an eastward shallow-dipping angle, compatible with the subduction geometry. Similar mechanisms are found at the Vichuquén cluster: their mechanism and their location close to the slab interface, with an average centroid depth of 43 $\mathrm{km}$, support they correspond to slip at the slab interface.

To extend the focal mechanism analysis to smaller earthquakes, we performed a waveform similarity analysis. We used only the vertical components of seismic recordings, apply a band-pass filter at $0.03-0.08 \mathrm{~Hz}$, extract $50 \mathrm{~s}$ long time windows and evaluate similarities among the seismic signals by waveform cross-correlation. For this analysis, we used only the stations GO05 and PEL, as they operated since 2012 and are located close to the clusters. Fig. 7 illustrates the waveform similarity for the GO05 station, considering 57 events with $\mathrm{M}_{\mathrm{L}} 3.5$ - 5.2 for the Navidad cluster and 60 events with $M_{L} 3.5$ - 5.2 for the Vichuquén cluster. We applied a waveform-based clustering procedure, based on the DBSCAN algorithm (Cesca et al. 2014; Cesca 2020), parameterized to require five events with a cross-correlation higher than 0.95 to define a cluster. Two families of waveforms are identified at the Navidad cluster. The first, larger one includes many earthquakes from different swarms. A second family includes events that typically occur out of any swarm episode, in the so-called inter-swarm periods (fig. S3). At the Vichuquén cluster we reconstruct a single family of events with similar waveforms, which is consistent with the compact spatial geometry of the Vichuquén cluster and the similarity of thrust mechanisms resolved for the largest events.

\subsection{Repeating earthquakes}

We repeated the waveform similarity analysis to identify repeaters, now imposing stronger conditions in the waveform similarity. We scanned all events considered in the cluster between 
2012 to 2020, including the events with magnitudes below the completeness threshold, extracted a 40 s time window of the raw seismogram for the vertical component starting at the origin time. The cut waveforms include both $\mathrm{P}$ and $\mathrm{S}$ phases, and after applying a 1-4 $\mathrm{Hz}$ band pass filter, we assessed the cross-correlation for each event pair (Igarashi et al. 2003). The band-pass filter is chosen below the corner frequency of all considered events, to avoid differences in high frequency waveform, according to Igarashi et al. (2003) and Kato et al. (2016). Repeating earthquakes are then identified when they display a cross correlation coefficient larger than 0.95 at two or more stations. For both clusters, we used the stations GO05 and PEL for the data before June 2014, and additionally included the stations B002, MT02, MT03 and MT05 for data from June 2014 onward.

We used the DBSCAN algorithm to identify families of repeaters for both clusters. We detected 168 repeating earthquakes for the Vichuquén cluster (excluding those cases where only event pairs are found), while we did not find repeaters at the Navidad cluster. We found 30 families of repeaters (i.e. with at least 3 events) and further analyzed the 15 largest families, with more than 5 events (Tab. 3, Fig. 8). We estimated the amount of associated slip from the moment release of repeating earthquakes using two approaches (Tab. 3): we first consider the relation

$$
d=M_{0} / \mu A
$$

where $\mu$ is the shear modulus, $A$ is the rupture area, and $d$ is the average slip; this equation was considered by Nadeau and Johnson (1998) for a crack model. Here, we estimated the rupture area from the moment magnitude, based on the empirical relation by Blaser et al. (2010) and assumed a shear modulus $\mu=39 \mathrm{GPa}$ (Agurto et al. 2012). The second approach is based on the empirical relation

$$
d=10^{-2.36} M_{0}^{0.17}
$$


proposed by Nadeau and Johnson (1998). The seismic moment is derived using the standard formula of Hanks and Kanamori (1979):

$$
\log \left(M_{0}\right)=1.5 M_{W}+9.1
$$

assuming $\mathrm{M}_{\mathrm{L}}=\mathrm{M}_{\mathrm{W}}$. We estimated the slip rate to be in the range of 0.7 to $4.2 \mathrm{~cm} / \mathrm{yr}$ for the crack model and in the range 1.8 to $5.0 \mathrm{~cm} / \mathrm{yr}$ for the empirical relation (Fig. 8, Table 3). This variability can be related to an incompleteness of the repeaters detection, spatial variability of the slip rate or the variations in the amounts of slip inferred from different relationships. Some more repeaters likely go undetected because of seismic noise fluctuations, data gaps, as well as some waveform dissimilarities for events with different magnitudes. The estimated slip rate should thus be treated as the lower limit of the real slip rate. Therefore, the largest value found for family 5 should be considered as the most reliable estimate.

\section{Discussion}

In the past years, many seismicity clusters were identified along the Chilean subduction zone, some of which have been suggested as precursors of megathrust earthquakes (Brodsky \& Lay 2014). This work contributes to the identification and characterization of seismicity clusters in Central Chile and the investigation of the possible mechanisms and processes behind them. In particular, we detected two clusters (Navidad and Vichuquén) that have been active for at least 20 years by mapping seismicity density and moment release and identifying spatio-temporal anomalies. Seismic clusters are usually a manifestation of stress transients such as aseismic slip and/or fluid transfer and pore pressure changes at depth and their analysis can provide information on these processes, which are typically poorly resolved from surface observations (Passarelli et al. 2018; Lohman \&

McGuire 2007; Ozawa et al. 2007; Wolfe et al. 2007; Bräuer et al. 2003). A key question remains 
whether the seismicity pattern of persistent seismic clusters may be used to detect and constrain the underlying process and act as high-resolution stress release sensors.

\subsection{Origin of the Navidad and Vichuquén clusters}

The Navidad and Vichuquén clusters exhibit high seismicity rates compared to the larger seismogenic volume in the Central Chile subduction segment (Fig. 2). Considering hypocentral distributions and moment tensors, the Vichuquén cluster is located at depths of $\sim 40 \mathrm{~km}$ at the plate interface In this scenario, lower seismicity around the Vichuquén cluster supports some kind of aseismic slip in the surrounding region of the slab interface. On the other hand, the shallower cluster offshore Navidad is located at depths of $\sim 20 \mathrm{~km}$ in the plate interface. Even though the two clusters generate a comparable moment release, they differ substantially in how this is released: the Navidad cluster presents swarm-type seismicity, releasing most energy via short-lasting bursts of activity, while the Vichuquén cluster has a more persistent activity over the entire period of almost 20 years and it is characterized by repeating earthquakes.

It is known that seismic swarms and clusters originate in regions of structural heterogeneities. Hill (1977) proposed that seismic swarms originate in highly heterogeneous seismogenic volumes characterized by the presence of fluids and pore pressure transients. However, the origin of seismic swarms is still debated, especially in the case of interplate seismicity. Moscoso et al. (2011) proposed that the margin at $34^{\circ}-35^{\circ} \mathrm{S}$ consists of three clear domains: accretionary prism, paleoaccretionary complex, and continental domain. The sequences of seismic swarms at Navidad are located at the boundary of the paleo-accretionary complex with the plate interface, where fracture processes, structural heterogeneities, and presence of fluids are expected. The swarm activity could thus be triggered by fluid transfer or pore pressure transients, repeatedly activating the same

fractured volume. A possible interpretation is that the swarm activity is caused by a localized 
reactivation of bending slab fractures, in response to fluid migration through the fractured plate and pore pressure, as proposed by Poli et al. (2017).

Seismic tomography along the Maule megathrust region illuminated at latitude $34.5^{\circ} \mathrm{S}$ a small-scale volume characterized by high P-wave velocity, which correlates with a marked positive gravity anomaly (Hicks et al. 2012). The authors interpreted this smaller anomaly - together with other larger anomalies found along the Maule rupture zone - as subducting topographic highs of dense mafic composition (Fig. 9). The P-wave and gravity anomalies co-locate within the volumes of the Vichuquén onshore cluster - as shown in Fig. 9 - with earthquake activity concentrated at the downdip edge of the anomalous body.

Topographic highs at the plate interface may act as strong asperities due to a local increase of the normal stresses due to a rigid elastic response of the overriding plate, locally hampering seismic activity at the interface (Scholz \& Small 1997). Laboratory sand-box models of subducting seamounts and geomorphological inspection of the fore-arc region show high fractured regions adjoining a seamount tunneling the interface and argue for a simple elastic response of the overriding plate (Dominguez et al. 1998; Watts et al. 2010). The segmentation introduced by a subducted seamount alters the interface roughness (Bilek et al. 2003; Wang \& Bilek 2014; AgurtoDetzel et al. 2019) and can produce weak plate coupling, high fluid circulation and enhanced microseismic activity along with aseismic creep (Mochizuki et al. 2008; Wang \& Bilek 2011). In particular, downdip the leading edge of the seamount, multiple ruptures are expected to occur on small to moderate size asperities due to concentration of compressional stresses (Dominguez et al. 1998; Mochizuki et al. 2008; Basset \& Watts 2015; Sun et al. 2020). This seems the most likely conditions in place at the nucleation region of the Vichuquén cluster, where the isolated earthquake activity manifests through families of repeating earthquakes suggesting multiple rupture on almost equally sized asperities loaded by the subducted topographic seamount (Fig. 9). 


\subsection{Seismicity clusters and large earthquakes}

During the inter-seismic stage of the seismic cycle, the convergence of the plates produces elastic deformation in the upper plate (Klotz et al. 1999; Pritchard et al. 2002; Chlieh et al. 2004). Surface deformation can be quantified through the use of geodetic data; by inverting these data, it is possible to obtain the inter-seismic coupling distribution. In Central Chile, different coupling models have been proposed (e.g. Métois et al. 2012, 2016; Moreno et al. 2012). The two cluster zones are located in regions between low to moderate values of seismic coupling (fig. S4a), where aseismic slip can take place accompanied by repeaters or swarm episodes.

Since both the Navidad and Vichuquén clusters have been active for the entire considered period starting before the Maule earthquake, we can characterize and discuss their rate of seismicity before, during and after this event. Seismicity rates at both clusters increased substantially after the Maule earthquake (Fig. 5a). Especially at the Vichuquén cluster, it is notable how the seismicity rate is increased for many years, suggesting a localized long-lasting afterslip, which is in agreement with the geodetically inferred significant afterslip close to the Vichuquén cluster (Peña et al. 2020, Fig. S4d). It is known that recurring earthquakes respond to stress induced by large earthquakes nearby with a shortening of inter-event time of repeaters that gradually increases to pre-mainshock levels in months to years (Schaff êt al. 1998; Nadeau \& McEvilly 2004; Uchida et al. 2003, 2015; Chen et al. 2010). Howeyer, the temporal anomaly at the Vichuquén cluster after the Maule earthquake appears to be exceptional: to date, ten years after the main shock, the seismicity has not yet recovered its level before the Maule megathrust event in 2010. In addition, the area of the Vichuquén cluster coincides with high aftershock concentration (Lange et al. 2012) and large afterslip (Agurto-Detzel et al. 2019, Peña et al 2020, fig. S4d). The seismicity rate at Vichuquén

may be read as a proxy for the regional aseismic slip in this subduction segment. 
Swarm activity has been observed prior to subduction earthquakes in Chile, e.g. the 1985 Valparaíso earthquake (Comte et al. 1986), 2014 Iquique earthquake (Ruiz S. et al. 2014; Schurr et al. 2014; Kato \& Nakagawa 2014), 2015 Illapel earthquake (Poli et al. 2017) and 2017 Valparaíso earthquake (Ruiz et al. 2017), and it has been discussed whether their observation can be used as an earthquake precursor. Our results give no general evidence of a precursory role of localized seismic activity. At Navidad, the seismicity is rather the result of a short-term perturbation of the slab system: regardless of whether fluid migration could affect pore pressure conditions and locally destabilize the slab interface, there is so far no evidence that this could accompany the nucleation of large earthquakes.

Swarm-like seismicity and repeating earthquakes are considered as characteristics of fluid-rich and geologically complex regions (Fagereng \& Sibson 2010). They may accompany slow slip events (Crescentini et al. 1999; Rogers \& Dragert 2003; Saffer \& Wallace 2015) and postseismic deformation (Nadeau \& Johnson 1998; Perfettini et al. 2010), as seen at the Vichuquén cluster after the Maule earthquake. It has been hypothesized that fluid-rich low coupling regions, such as those at Navidad and Vichuquén, may act as barriers against the propagation of large megathrust earthquake arresting efficiently the rupture propagation (Holtkamp \& Brudzinski 2014). These regions may also be characterized by high seismicity rates in the interseismic and postseismic periods (Sammonds et al. 1992; Schlaphorst et al. 2016).

\section{Conclusion}

This work identified two localized regions with anomalous seismicity along with the central Chile subduction interface. These seismicity clusters located offshore Navidad and onshore near Vichuquén appear as long term seismicity features, persisting for almost two decades, independent from the occurrence of large earthquakes, starting well before the Maule earthquake and continuing 
moment release, Benioff Strain, and inter-event time distributions. The temporal evolution of the two spots varies considerably. At the Navidad cluster, seismicity occurs in forms of swarm-like activity, with the largest swarm episodes in 2001, 2002, 2004, 2011, 2012, 2014 and 2018 showing some rough temporal recurrence. At the Vichuquén cluster, the analysis of inter-event time resembles a more random Poisson occurrence and the presence of repeating earthquakes.

Hypocentral locations and thrust faulting focal mechanisms at the Vichuquén cluster support the interpretation that seismicity occurs at the subduction interface. The sustained occurrence of repeaters and the lack of a clear migration pattern over time are most plausibly explained by the presence of a localized structural or topographic anomaly in the subducting slab. The modulation of the seismicity by the Maule earthquake is also noteworthy. While it is not/surprising that the seismicity cluster is active before and after the megathrust event, the Maule earthquake considerably enhanced the activity at the Vichuquén cluster. At present the seismicity rate is still larger than before the megathrust event. This suggests ongoing and long-lasting aseismic slip triggering seismic energy release at the Vichuquén asperity.

The different inter-event times statistics and skewness analysis at the Navidad cluster reveal its swarm-like activity. In this work, we identified 9 swarm episodes at the Navidad cluster, the largest one in November in 2012. The focal mechanisms and the spatial distribution show that seismicity occurring in the swarm episodes corresponds to thrust faulting at the subduction interface.

In conclusion, we attribute the Vichuquén cluster to a structural or topographic heterogeneity such as a subducted seamount, which acts as an asperity and is repeatedly activated through highly similar earthquakes. The swarm-like Navidad cluster is the response to fluid transfer or pore pressure transients that activate a fractured volume of the subducting plate. Both processes have 
been observed over almost two decades, partially modulated by the occurrence of the Maule earthquake, and will presumably remain active in the future.

\section{Acknowledgments}

We acknowledge the editor, Dr. Martin Schimmel, Dr. Agurto-Detzel and an anonymous reviewer for their useful suggestions. C.V. acknowledges the scholarship granted by the National Commission for Scientific and Technological Research (CONICYT - Becas Chile). The seismic catalogue was provided by the Centro Sismológico Nacional (CSN, Chile; http://www.sismologia.cl/, last accessed 15.03.2020), waveforms used pertains to the following networks: Red Sismologica Nacional (RSN), C1 (Universidad de Chile, 2012), Chilean National

Seismic Network, C (https://www.fdsn.org/networks/detail/C/) and Geoscope, G (IPGP, 1982). Seismological data and metadata were accessed through the IRIS web service.

\section{References}

Agurto, H., Rietbrock, A., Ryder, I., \& Miller, M. (2012). Seismic $\square$ afterslip characterization of the 2010 Mw 8.8 Maule, Chile, earthquake based on moment tensor inversion. Geophysical Research Letters, 39(20).

Agurto-Detzel, H., Font, Y., Charvîs, P., Régnier, M., Rietbrock, A., Ambrois, D., ... \& De Barros,

L. (2019). Ridge subduction and afterslip control aftershock distribution of the $2016 \mathrm{Mw} 7.8$ Ecuador earthquake. Earth and Planetary Science Letters, 520, 63-76.

Ammirati, J.B, Vargas, G., Rebolledo, S., Abrahami, R., Potin, B, Leyton, F., and Ruiz, S.(2019).

The crustal seismicity of the western Andean thrust (central Chile, 33-34 ${ }^{\circ}$ S): Implications for regional tectonics and seismic hazard in Santiago area. Bulletin of the Seismological Society of 
Barrientos, S. and National Seismological Center (CSN) Team, 2018. The seismic network of Chile. Seismological Research Letters, 89(2A), pp.467-474.

Bassin, C., Laske, G., \& Masters, G. (2000). The current limits of resolution for surface wave tomography in North America. Eos, 81.

Båth, Markus. (1965). Lateral inhomogeneities of the upper mantle. Tectonophysics, 2(6), 483-514.

Benioff, H. (1951). Global strain accumulation and release as revealed by great earthquakes. Geological Society of America Bulletin, 62(4), 331-338.

Bilek, S., Schwartz, S. \& DeShon, H. (2003). Control of seafloor roughness on earthquake rupture behavior. Geology, 31(5), 455-458.

Blaser, L., Krüger, F., Ohrnberger, M., \& Scherbaum, F. (2010). Scaling relations of earthquake source parameter estimates with special focus on subduction environment. Bulletin of the Seismological Society of America, 100(6), 2914-2926.

Bräuer, K., Kämpf, H., Strauch, G., \& Weise, S. M. (2003). Isotopic evidence (3He/4He, of fluid $\square$ triggered intraplate seismicity.m Journal of Geophysical Research: Solid Earth, 108(B2).

Brodsky, E. E., \& Lay, T. (2014). Recognizing foreshocks from the 1 April 2014 Chile earthquake.

Science, 344(6185), 700-702. 
Cesca, S., Heimann, S., Stammler, K., \& Dahm, T. (2010): Automated procedure for point and kinematic source inversion at regional distances. Journal of Geophysical Research, 115.

Cesca, S., Şen, A. T., \& Dahm, T. (2014). Seismicity monitoring by cluster analysis of moment tensors. Geophysical Journal International, 196(3), 1813-1826.

Cesca, S., Grigoli, F., Heimann, S., Dahm, T., Kriegerowski, M., Sobiesiak, M., Tassara, C., \& Olcay, M. (2016). The M w 8.12014 Iquique, Chile, seismic sequence: a tale of foreshocks and aftershocks. Geophysical Journal International, 204(3), 1766-1780.

Cesca, S. (2020). Seiscloud, a tool for density-based seismicity clustering and visualization. J. Seismol., in review.

Chen, K. H., Bürgmann, R., Nadeau, R. M., Chen, T., \& Lapusta, N. (2010). Postseismic variations in seismic moment and recurrence interval of repeating earthquakes. Earth and Planetary Science Letters, 299(1-2), 118-125.

Chen, X., \& Shearer, P. M. (2011). Comprehensive analysis of earthquake source spectra and swarms in the Salton Trough, California. Journal of Geophysical Research: Solid Earth, 116(B9).

Chlieh, M., De Chabalier, J., Ruegg, J., Armijo, R., Dmowska, R., Campos, J., \& Feigl, K. (2004). Crustal deformation and fault slip during the seismic cycle in the North Chile subduction zone, from GPS and InSAR observations. Geophysical Journal International, 158(2), 695-711. 
Comte, D., Eisenberg, A., Lorca, E., Pardo, M., Ponce, L., Saragoni, R., Singh, S., \& Suárez, G. (1986). The 1985 central Chile earthquake: a repeat of previous great earthquakes in the region? Science, 233(4762), 449-453.

Comte, D., Tassara, A., \& Farías, M. (2007). Análisis del enjambre sísmico de Copiapó, 2006: sismicidad histórica y contacto interplaca. Santiago: inédito, Departamento de Geofísica, Universidad de Chile.

Crescentini, L., Amoruso, A., \& Scarpa, R. (1999). Constraints on slow earthquake dynamics from a swarm in central Italy. Science, 286(5447), 2132-2134.

Dominguez, S., Lallemand, S. E., Malavieille, J., \& von Huene, R. (1998). Upper plate deformation associated with seamount subduction. Tectonophysics, 293(3-4), 207-224.

Ellsworth, W. L., \& Beroza, G. C. (1995). Seismic evidence for an earthquake nucleation phase. Science, 268(5212), 851-855.

Fagereng, Å., \& Sibson, R. H. (2010). Melange rheology and seismic style. Geology, 38(8), 751754.

Farías, M., Comte, D,, Roecker, S., Carrizo, D., \& Pardo, M. (2011). Crustal extensional faulting triggered by the 2010 Chilean earthquake: The Pichilemu Seismic Sequence. Tectonics, 30(6).

Gardi, A., Lemoine, A., Madariaga, R., \& Campos, J. (2006). Modeling of stress transfer in the Coquimbo region of central Chile. Journal of Geophysical Research: Solid Earth, 111(B4). 
Gutenberg, B., \& Richter, C. (1956). Magnitude and energy of earthquakes. Annals of Geophysics, $9(1), 1-15$.

Hainzl, S. (2003). Self-organization of earthquake swarms. Journal of Geodynamics, 35(1), 157172.

Hanks, T. C., \& Kanamori, H. (1979). A moment magnitude scale. Journal of Geophysical Research: Solid Earth, 84(B5), 2348-2350.

Hicks, S. P., Rietbrock, A., Haberland, C. A., Ryder, I., Simons, M., \& Tassara, A. (2012). The 2010 Mw 8.8 Maule, Chile earthquake: Nucleation and rupture propagation controlled by a subducted topographic high. Geophysical Research Letters, 39(19).

Hill, D P. (1977). A model for earthquake swarms. Journal of Geophysical Research, 82(8), 13471352.

Holtkamp, S. G., \& Brudzinski, M. R. (2011). Earthquake swarms in circum-Pacific subduction zones. Earth and Planetary Science Letters, 305(1), 215-225.

Holtkamp, S. G., Pritchard, M. E., \& Lohman, R. B. (2011). Earthquake swarms in South America. Geophysical Journal International, 187(1), 128-146.

Holtkamp, S. G., \& Brudzinski, M. R. (2014). Megathrust earthquake swarms indicate frictional changes which delimit large earthquake ruptures. Earth and Planetary Science Letters, 390, 234- 
Institut De Physique Du Globe De Paris (IPGP), \& Ecole Et Observatoire Des Sciences De La Terre De Strasbourg (EOST). (1982). GEOSCOPE, French Global Network of broad band seismic stations. Institut de Physique du Globe de Paris (IPGP). https://doi.org/10.18715/GEOSCOPE.G

Igarashi, T., Matsuzawa, T., \& Hasegawa, A. (2003). Repeating earthquakes and interplate aseismic slip in the northeastern Japan subduction zone. Journal of Geophysical Research: Solid Earth, 108(B5).

Kagan, Y. Y., \& Jackson, D. D. (1991). Long-term earthquake clustering. GeophysicalJournal International, 104(1), 117-133.

Kagan, Y. Y. (1991). 3-D rotation of double-couple earthquake sources. Geophysical Journal International, 106(3), 709-716.

Kagan, Y. Y. (1992). Correlations of earthquake focal mechanisms. Geophysical Journal International, 110(2), 305-320.

Kanamori, H., \& Anderson, D. L. (1975). Theoretical basis of some empirical relations in seismology. Bulletin of the seismological society of America, 65(5), 1073-1095.

Kato, A., \& Nakagawa, S. (2014). Multiple slow $\square$ slip events during a foreshock sequence of the 2014 Iquique, Chile Mw 8.1 earthquake. Geophysical Research Letters, 41(15), 5420-5427.

Kato, A., Fukuda, J. I., Kumazawa, T., \& Nakagawa, S. (2016). Accelerated nucleation of the 2014 Iquique, Chile Mw 8.2 earthquake. Scientific reports, 6, 24792. 
Khoshmanesh, M., Shirzaei, M., \& Nadeau, R. M. (2015). Time $\square$ dependent model of aseismic slip on the central San Andreas Fault from InSAR time series and repeating earthquakes. Journal of Geophysical Research: Solid Earth, 120(9), 6658-6679.

Kisslinger, C. (1975). Processes during the Matsushiro, Japan, earthquake swarm as revealed by leveling, gravity, and spring-flow observations. Geology, 3(2), 57-62.

Klotz, J., Angermann, D., Michel, G., Porth, R., Reigber, C., Reinking, J., Viramonte, J., Perdomo, R., Rios, V., \& Barrientos, S. (1999). GPS-derived deformation of the Central Andes including the 1995 Antofagasta M w= 8.0 earthquake. Pages 709-730 of: Seismogenic and Tsunamigenic Processes in Shallow Subduction Zones. Springer.

Lange, D., Tilmann, F., Barrientos, S. E., Contreras-Reyes, E., Methe, P., Moreno, M., Heit, B., Agurto, H., Bernard, P., Vilotte, JP. \& Beck, S. (2012). Aftershock séismicity of the 27 February 2010 Mw 8.8 Maule earthquake rupture zone. Earth and Planetary Science Letters, 317, 413-425.

Lohman, R., \& McGuire, J. (2007). Earthquake swarms driven by aseismic creep in the Salton Trough, California. Journal of Geophysical Research: Solid Earth (1978-2012), 112(B4).

Madariaga, R., Métois, M., Vigny, C., \& Campos, J. (2010). Central Chile finally breaks. Science, 328(5975), 181-182.

Maghsoudi, S., Hainzl, S., Cesca, S., Dahm, T., \& Kaiser, D. (2013). Identification and characterization of growing large scale en echelon fractures in a salt mine. Geophysical Journal. 
Matthews, M.V., \& Reasenberg, P.A., (1988). Statistical methods for investigating qui-escence and other temporal seismicity patterns. Pure Appl. Geophys.126 (2), 357-372.

Meng, L., Huang, H., Bürgmann, R., Ampuero, J. P., \& Strader, A. (2015). Dual megathrust slip behaviors of the 2014 Iquique earthquake sequence. Earth and Planetary Science Letters, 411, 177187.

Métois, M., Socquet, A., \& Vigny, C. (2012). Interseismic coupling, segmentation and mechanical behavior of the central Chile subduction zone. Journal of Geophysical Research: Solid Earth, 117(B3).

Métois, M., Vigny, C., \& Socquet, A. (2016). Interseismic coupling, megathrust earthquakes and seismic swarms along the Chilean subduction zone (38-18 S). Pure and Applied Geophysics, 173(5), 1431-1449.

Mochizuki, K., Yamada, T., Shinohara, M., Yamanaka, Y., \& Kanazawa, T. (2008). Weak interplate coupling by seamounts and repeating $M \sim$ 7 earthquakes. Science, 321(5893), 1194-1197.

Moreno, M., Melnick, D., Rosenau, M., Baez, J., Klotz, J., Oncken, O., Tassara, A., Chen, J., Bataille, K., Bevis, M., Socquet, A., Bolte, J., Vigny, C., Brooks, B., Ryder, I., Grund, V., Smalley, B., Carrizo, D. \& Hase, H. (2012). Toward understanding tectonic control on the Mw 8.82010 Maule Chile earthquake. Earth and Planetary Science Letters, 321, 152-165.

Moscoso, E., Grevemeyer, I., Contreras-Reyes, E., Flueh, E. R., Dzierma, Y., Rabbel, W., \& Thorwart, M. (2011). Revealing the deep structure and rupture plane of the 2010 Maule, Chile 
earthquake $(\mathrm{Mw}=8.8)$ using wide angle seismic data. Earth and Planetary Science Letters, 307(1), $147-155$.

Nadeau, R. M., \& Johnson, L. R. (1998). Seismological studies at Parkfield VI: Moment release rates and estimates of source parameters for small repeating earthquakes. Bulletin of the Seismological Society of America, 88(3), 790-814.

Nadeau, R. M., \& McEvilly, T. V. (1999). Fault slip rates at depth from recurrence intervals of repeating microearthquakes. Science, 285(5428), 718-721.

Nadeau, R. M., \& McEvilly, T. V. (2004). Periodic pulsing of characteristic microearthquakes on the San Andreas Fault. Science, 303(5655), 220-222.

Nealy, J. L., Herman, M. W., Moore, G. L., Hayes, G. P., Benz, H. M., Bergman, E. A., \& Barrientos, S. E. (2017). 2017 Valparaíso earthquake sequence and the megathrust patchwork of central Chile, Geophys. Res. Lett., https://doi.org/10.1002/2017GL074767

Noir, J., Jacques, E., Bekri, S., Adler, P. M., Tapponnier, P., \& King, G. C. P. (1997). Fluid flow triggered migration of events in the 1989 Dobi earthquake sequence of Central Afar. Geophysical Research Letters, 24(18), 2335-2338.

Omori, F. (1894). Inyestigation of aftershocks. Rep. Earthquake Inv. Comm, 2, 103-139. Paige, C, \& Saunders, MA. 1982. LSQR: An algorithm for sparse linear equations and sparse least squares. ACM Transactions on Mathematical Software (TOMS), 8(1), 43-71. 
Ozawa, S., Suito, H., \& Tobita, M. (2007). Occurrence of quasi-periodic slow-slip off the east coast of the Boso peninsula, Central Japan. Earth, planets and space, 59(12), 1241-1245.

Peña, C., Heidbach, O., Moreno, M., Bedford, J., Ziegler, M., Tassara, A., \& Oncken, O. (2020). Impact of power-law rheology on the viscoelastic relaxation pattern and afterslip distribution following the $2010 \mathrm{Mw} 8.8$ Maule earthquake. Earth and Planetary Science Letters, 542, 116292.

Passarelli, L., Hainzl, S., Cesca, S., Maccaferri, F., Mucciarelli, M., Roessler, Dahm, T. \& Rivalta, E. (2015). Aseismic transient driving the swarm-like seismic sequence in the Pollino range, Southern Italy. Geophysical Journal International, 201(3), 1553-1567.

Passarelli, L., Rivalta, E., Jónsson, S., Hensch, M., Metzger, S., Jakobsđóttir, S., Maccaferri, F., Corbi, F. \& Dahm, T. (2018). Scaling and spatial complementarity of tectonic earthquake swarms. Earth and Planetary Science Letters, 482, 62-70.

Perfettini, H., Avouac, J. P., Tavera, H., Kositsky, A., Nocquet, J. M., Bondoux, F., Chlieh, M., Sladen, A., Audin, L., Faber, D., \& Soler, P.(2010). Seismic and aseismic slip on the Central Peru megathrust. Nature, 465(7294), 78.

Poli, P., Maksymowicz, A., \& Ruiz, S. (2017). The Mw 8.3 Illapel earthquake (Chile): Preseismic and postseismic activity associated with hydrated slab structures. Geology, 45(3), 247-250.

Potin, B. (2016). Les Alpes occidentales: tomographie, localisation de séismes et topographie du Moho (Doctoral dissertation, Grenoble Alpes). 
Pritchard, M., Simons, M., Rosen, P., Hensley, S., \& Webb, F. (2002). Co-seismic slip from the 1995 July $30 \mathrm{Mw}=8.1$ Antofagasta, Chile, earthquake as constrained by InSAR and GPS observations. Geophysical Journal International, 150(2), 362-376.

Rogers, G., \& Dragert, H. (2003). Episodic tremor and slip on the Cascadia subduction zone: The chatter of silent slip. Science, 300(5627), 1942-1943.

Roland, E., \& McGuire, J. J. (2009). Earthquake swarms on transform faults. Geophysical Journal International, 178(3), 1677-1690.

Roth, F., Dahm, T., \& Hainzl, S. (2017). Testing stress shadowing effects at the South American subduction zone. Geophysical Journal International, 211(2), 1272-1283.

Ruiz, J., Hayes, G., Carrizo, D., Kanamori, H., Socquet, A., \& Comte, D. (2014). Seismological analyses of the 2010 March 11, Pichilemu, Chile Mw 7.0 and Mw 6.9 coastal intraplate earthquakes. Geophysical Journal International, 197(1),414-434.

Ruiz, S., Madariaga, R., Astroza, M., Saragoni, R., Lancieri, M., Vigny, C., \& Campos, J. (2012). Short-Period rupture process of the 2010 Mw 8.8 Maule earthquake in Chile. Earthquake Spectra, 28(S1), S1-S18.

Ruiz, S., Métois, M.,Fuenzalida, A., Ruiz, J., Leyton, F., Grandin, R., Vigny, C., Madariaga, R., \& Campos, J. (2014). Intense foreshocks and a slow slip event preceded the 2014 Iquique Mw 8.1 earthquake. Science, 345(6201), 1165-1169. 
Ruiz, S., Aden $\square$ Antoniow, F., Baez, J. C., Otarola, C., Potin, B., del Campo, F., Poli, P., Flores, C., Satriano, C., Leyton, F., Madariaga, R. \& Bernard, P. (2017). Nucleation phase and dynamic inversion of the Mw 6.9 Valparaíso 2017 earthquake in Central Chile. Geophysical Research Letters, 44(20), 10-290.

Ruiz, S., \& Madariaga, R. (2018). Historical and recent large megathrust earthquakes in Chile. Tectonophysics, 733, 37-56.

Ruiz ,S., Ammirati, J.B, Leyton, F., Cabrera, L, Potin, B and Madariaga, R.(2019). The January 2019 (Mw 6.7) Coquimbo earthquake: Insights from a seismic sequence within the Nazca plate. Seismological Research Letters. doi: 10.1785/0220190079

Saffer, D. M., \& Wallace, L. M. (2015). The frictional, hydrologic, metamorphic and thermal habitat of shallow slow earthquakes. Nature Geoscience.

Sammonds, P. R., Meredith, P. G., \& Main, I. G. (1992). Role of pore fluids in the generation of seismic precursors to shear fracture. Nature, 359(6392), 228.

Schaff, D. P., Beroza, G. C., \& Shaw, B. E. (1998). Postseismic response of repeating aftershocks. Geophysical Research Letters, 25(24), 4549-4552.

Schlaphorst, D., Kendall, J. M., Collier, J. S., Verdon, J. P., Blundy, J., Baptie, B., Latchman, J., Massin, F. \& Bouin, M. P. (2016). Water, oceanic fracture zones and the lubrication of subducting plate boundaries-insights from seismicity. Geophysical Journal International, 204(3), 1405-1420. 
Scholz, C. H., \& Small, C. (1997). The effect of seamount subduction on seismic coupling. Geology, 25(6), 487-490.

Schorlemmer, D., Wiemer, S., \& Wyss, M. (2005). Variations in earthquake-size distribution across different stress regimes. Nature, 437(7058), 539-542.

Schurr, B., Asch, G., Hainzl, S., Bedford, J., Hoechner, A., Palo, M., Wang, R., Moreno, M., Bartsch, M., Zhang, Y., Oncken, O., Tilmann, F., Dahm, T., Victor, P., Barrientos, S. \& Vilotte, JP. (2014). Gradual unlocking of plate boundary controlled initiation of the 2014 Iquique earthquake. Nature, 512(7514), 299.

Soto, H., Sippl, C., Schurr, B., Kummerow, J., Asch, G., Tilmann, F., Comte, D., Ruiz, S. \& Oncken, O. (2019). Probing the Northern Chile Megathrust With Seismicity: The 2014 M8. 1 Iquique Earthquake Sequence. Journal of Geophysical Research: Solid Earth, 124(12), 1293512954.

Sun, T., Saffer, D., \& Ellis, S. (2020). Mechanical and hydrological effects of seamount subduction on megathrust stress and slip. Nature Geoscience, 13(3), 249-255.

Sykes, L. R. (1970). Earthquake swarms and sea-floor spreading. Journal of Geophysical Research, 75(32), 6598-6611.

Uchida, N., Matsuzawa, T., Hasegawa, A., \& Igarashi, T. (2003). Interplate quasi $\square$ static slip off Sanriku, NE Japan, estimated from repeating earthquakes. Geophysical Research Letters, 30(15). 
Uchida, N., Shimamura, K., Matsuzawa, T., \& Okada, T. (2015). Postseismic response of repeating earthquakes around the 2011 Tohoku $\square$ oki earthquake: Moment increases due to the fast loading rate. Journal of Geophysical Research: Solid Earth, 120(1), 259-274.

Udías, A., Madariaga, R., Buforn, E., Muñoz, D., \& Ros, M. (2012). The large Chilean historical earthquakes of $1647,1657,1730$, and 1751 from contemporary documents. Bulletin of the Seismological Society of America, 102(4), 1639-1653.

Universidad de Chile (2012): Red Sismologica Nacional. International Federation of Digital Seismograph Networks. Dataset/Seismic Network. 10.7914/SN/C1, Y doi: https://doi.org/10.7914/SN/C1

Vallée, M., Nocquet, J. M., Battaglia, J., Font, Y., Segovia, M., Regnier, M., Mothes, P., Jarrin, P., Cisneros, D., Vaca, S., Yepes, H., Martin, X., Béthoux, N., \& Chlieh, M. (2013). Intense interface seismicity triggered by a shallow slow slip event in the Central Ecuador subduction zone. Journal of Geophysical Research: Solid Earth, 118(6), 2965-2981.

Vidale, J. E., Hotovec, A. J., Ghosh, A., Creager, K. C., \& Gomberg, J. (2011). Tiny intraplate earthquakes triggered by nearby episodic tremor and slip in Cascadia. Geochemistry, Geophysics, Geosystems, 12(6).

Vigny, C., Rudloff, A., Ruegg, J. C, Madariaga, R., Campos, J., \& Alvarez, M. (2009). Upper plate deformation measured by GPS in the Coquimbo Gap, Chile. Physics of the Earth and Planetary Interiors, 175(1), 86-95. 
Waldhauser, F., \& Ellsworth, W L. (2000). A double-difference earthquake location algorithm: Method and application to the northern Hayward fault, California. Bulletin of the Seismological Society of America, 90(6), 1353-1368.

Wang, K., \& Bilek, S. L. (2011). Do subducting seamounts generate or stop large earthquakes?. Geology, 39(9), 819-822.

Wang, K., \& Bilek, S. L. (2014). Invited review paper: Fault creep caused by subduction of rough seafloor relief. Tectonophysics, 610, 1-24.

Watts, A. B., Koppers, A. A., \& Robinson, D. P. (2010). Seamount subduction and earthquakes. Oceanography, 23(1), 166-173.

Wiemer, S., \& Wyss, M. (2000). Minimum magnitude of completeness in earthquake catalogs: Examples from Alaska, the western United States, and Japan. Bulletin of the Seismological Society of America, 90(4), 859-869.

Wolfe, C. J., Brooks, B. A., Foster, J.H., \& Okubo, P. G. (2007). Microearthquake streaks and seismicity triggered by slow earthquakes on the mobile south flank of Kilauea Volcano, Hawaii. Geophysical Research Letters, 34(23).

Yamashita, T. (1999). Pore creation due to fault slip in a fluid-permeated fault zone and its effect on seismicity: generation mechanism of earthquake swarm. In Seismicity Patterns, Their Statistical Significance and Physical Meaning (pp. 625-647). Birkhäuser, Basel. 
Zöller, G., Hainzl, S., Ben-Zion, Y., \& Holschneider, M. (2006). Earthquake activity related to seismic cycles in a model for a heterogeneous strike-slip fault. Tectonophysics, 423(1-4), 137-145. 
Figures and captions

Figure 1

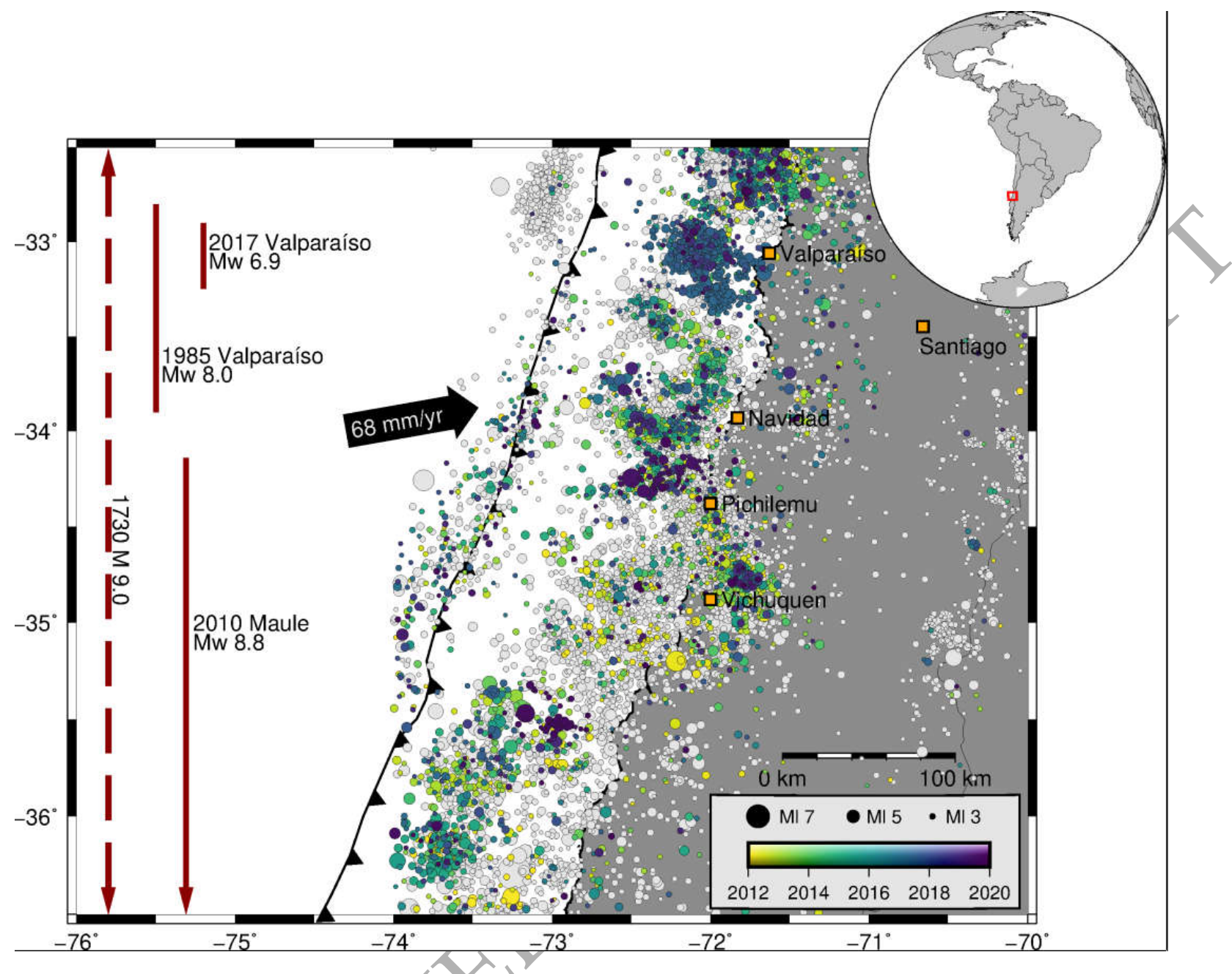

Figure 1. Map showing the seismicity in the study area. Colored circles show the epicentral locations of earthquakes between 2012 and 2020, and gray circles show the epicentral locations of earthquakes between 2000 and 2012. The size of each circle is scaled to magnitude. On the left side, the dark red lines display historical thrust earthquake ruptures since 1980 and the dashed line displays the mega-earthquake rupture in 1730 . 
Figure 2

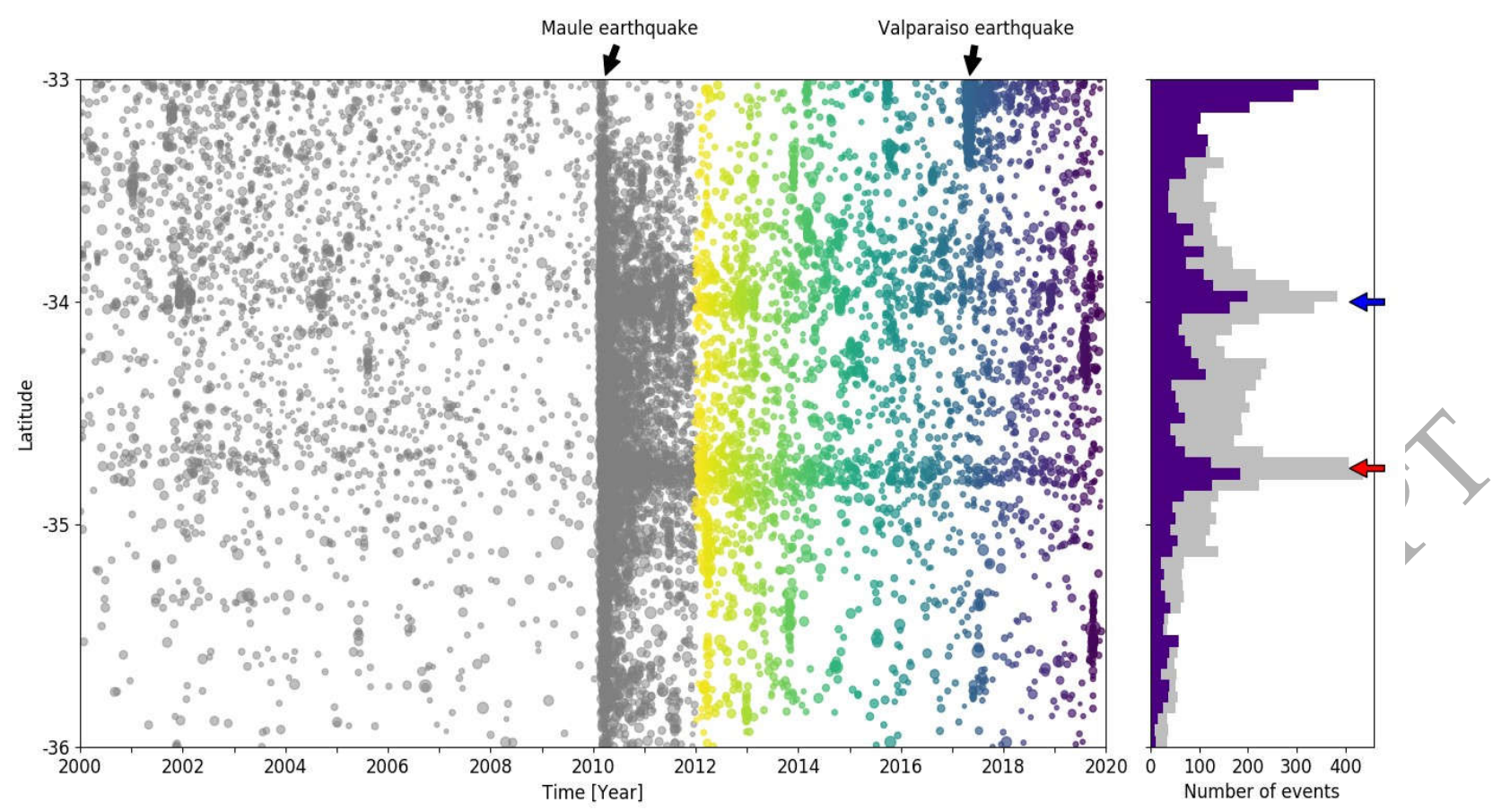

Figure 2. (left) Seismicity of the study area as a function of latitude and time. Dots in gray color corresponds to the events before 2012.0 and the colored dots correspond to events after 2012.0. (right) Histogram of the seismicity by latitude. The number of events is plotted per 0.05 degrees of latitude. The purple histogram represents the events between 2012 and 2020 (color events), and the gray histogram represents the events between 2000 and 2012 (gray events). The two color-coded arrows indicate the largest peaks in the histograms and correlate with the two persistent clusters identified in this study. 


\section{Figure 3}

(a)

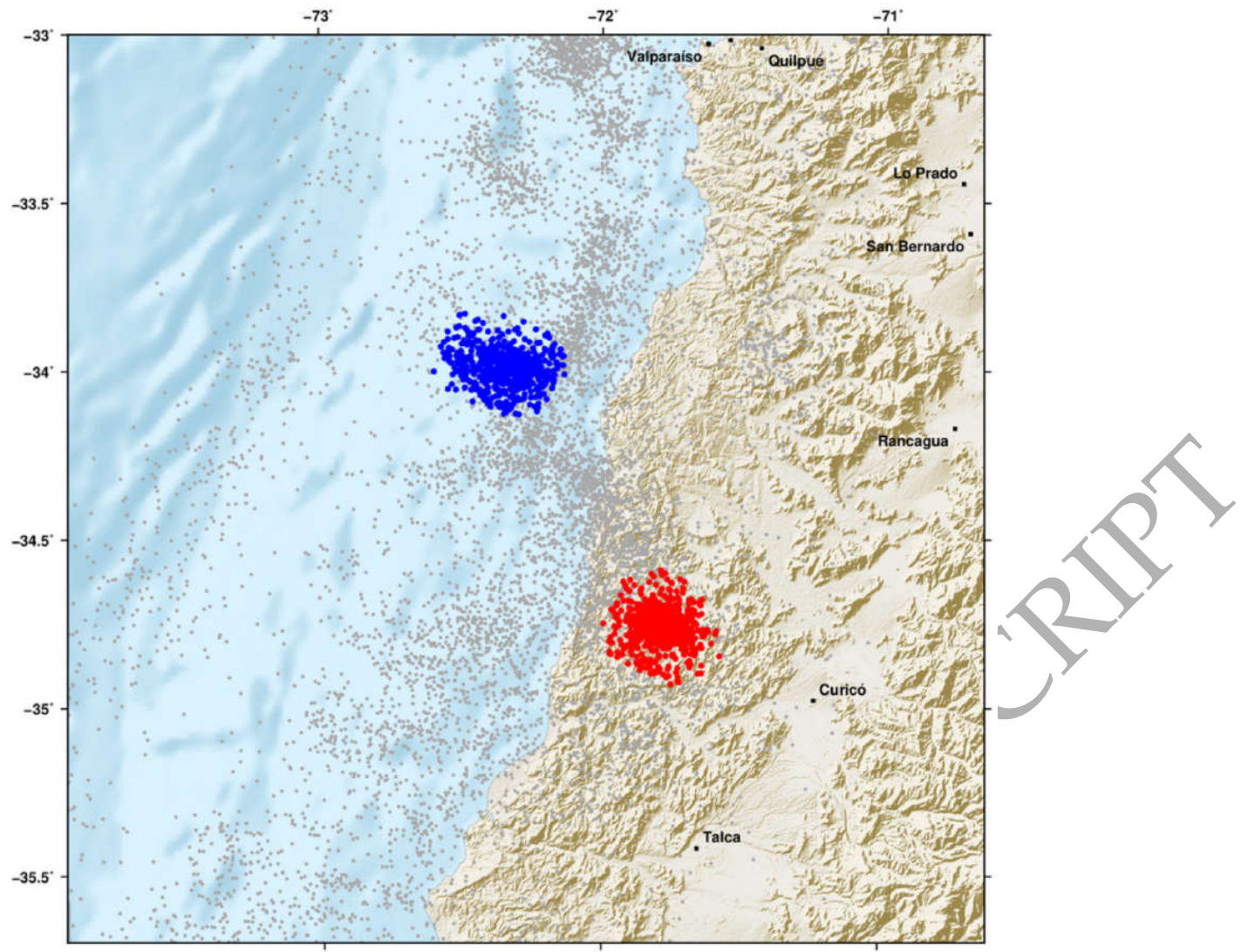

(b)
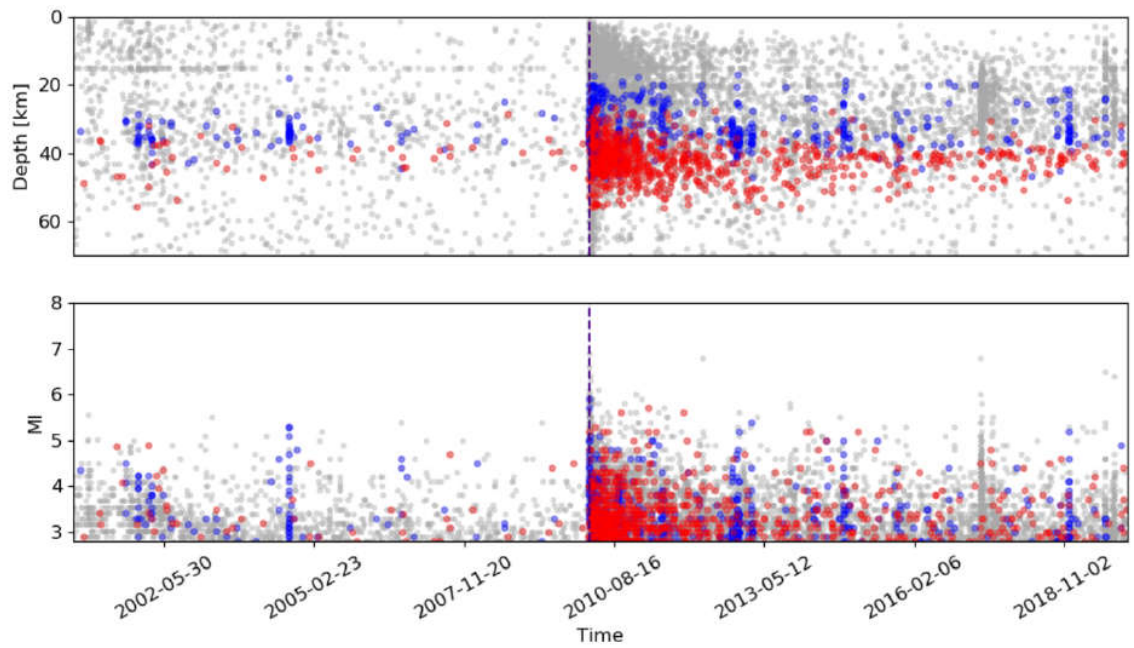

Figure 3. (a) Result of the 3D spatial, hypocentral clustering for the time period 2000-2020: earthquakes at the Navidad clusters are plotted in blue, those of the Vichuquén cluster in red, and unclustered events plus events in the third cluster in gray. (b) Temporal evolution of magnitude and depth (circle colors according to panel a). 


\section{Figure 4}

a)
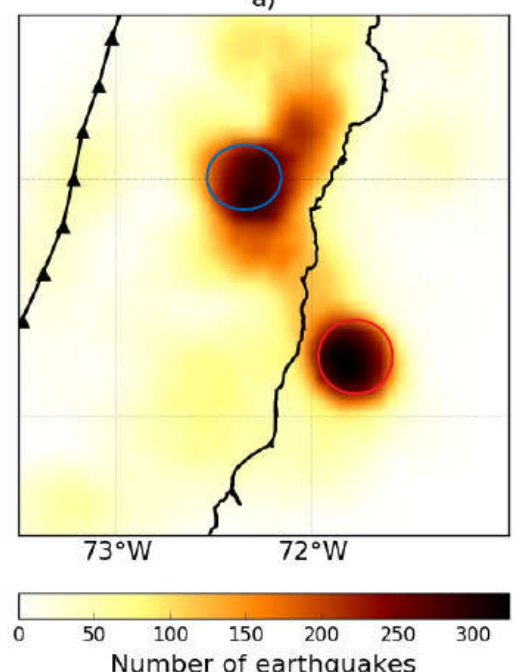

c)
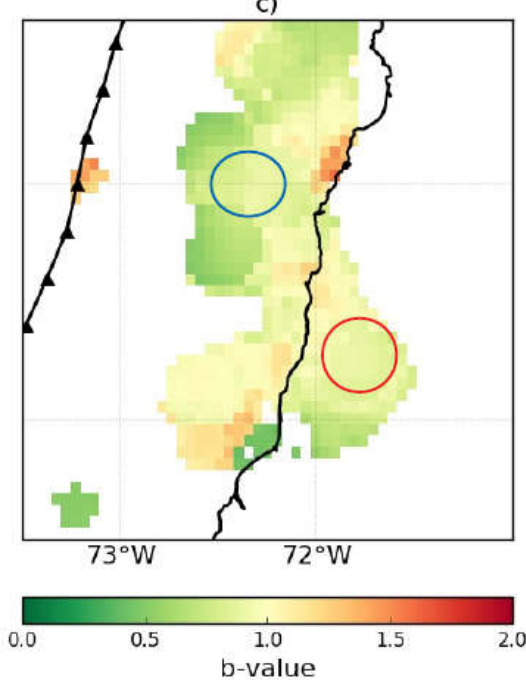

b)
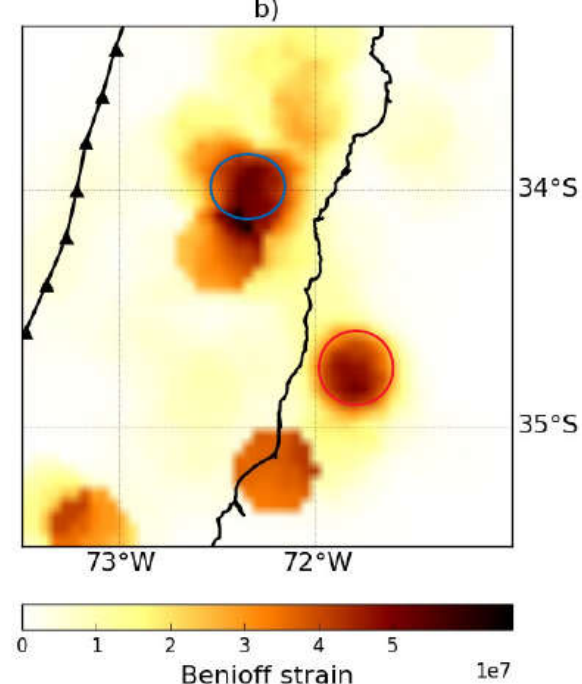

d)
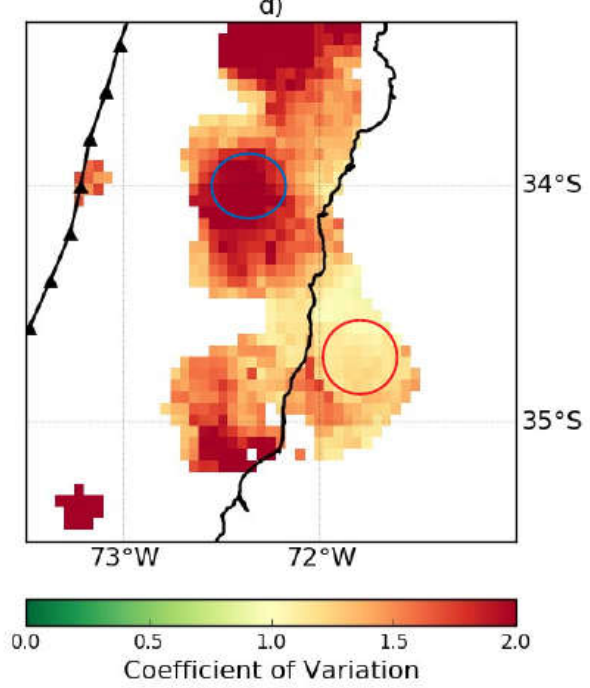

Figure 4. Regional maps of seismicity parameters per cell (grid 0.05 degrees, cells with radius 20 $\mathrm{km}$ and height $70 \mathrm{~km}$ ), based on the analysis of the 2012-2020 seismic catalogue (blue and red lines contour the Navidad and Vichuquén clusters, respectively): (a) number of earthquakes, (b) cumulative Benioff strain (the three dark spots at locations different from the cluster are due to single large-magnitude earthquakes that accumulate large amounts of Benioff strain), (c) b-value and (d) coefficient of variation for inter-event times. 


\section{Figure 5}
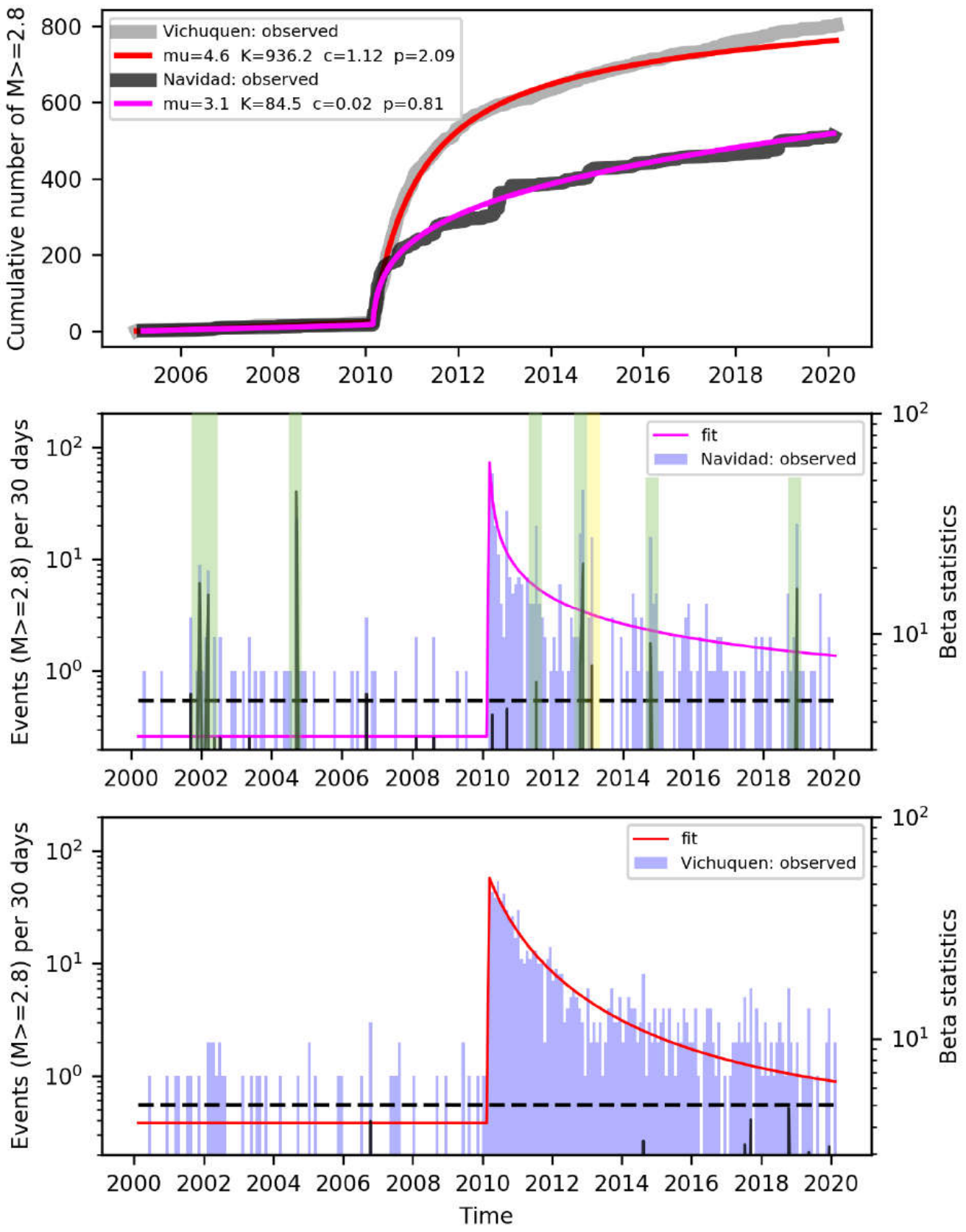

Figure 5. Time-clusters detection using beta statistics from the CSN catalogue $\left(\mathrm{M}_{\mathrm{L}} \geq 2.8\right)$. The black line is the beta statistics result in 30 days non-overlapping time window. The horizontal dashed line shows the $5 x$ standard-deviation threshold used to identify anomalies in the seismicity rate. (a) background seismicity rate and seismicity rate for both clusters, (b) beta statistics result for the Navidad cluster and (c) for the Vichuquén cluster. The green shaded bands in b) indicates the detected seismic swarm activity, the yellow shaded band a case of detected activity that we attribute to a mainshock sequence (high skew). 
Figure 6
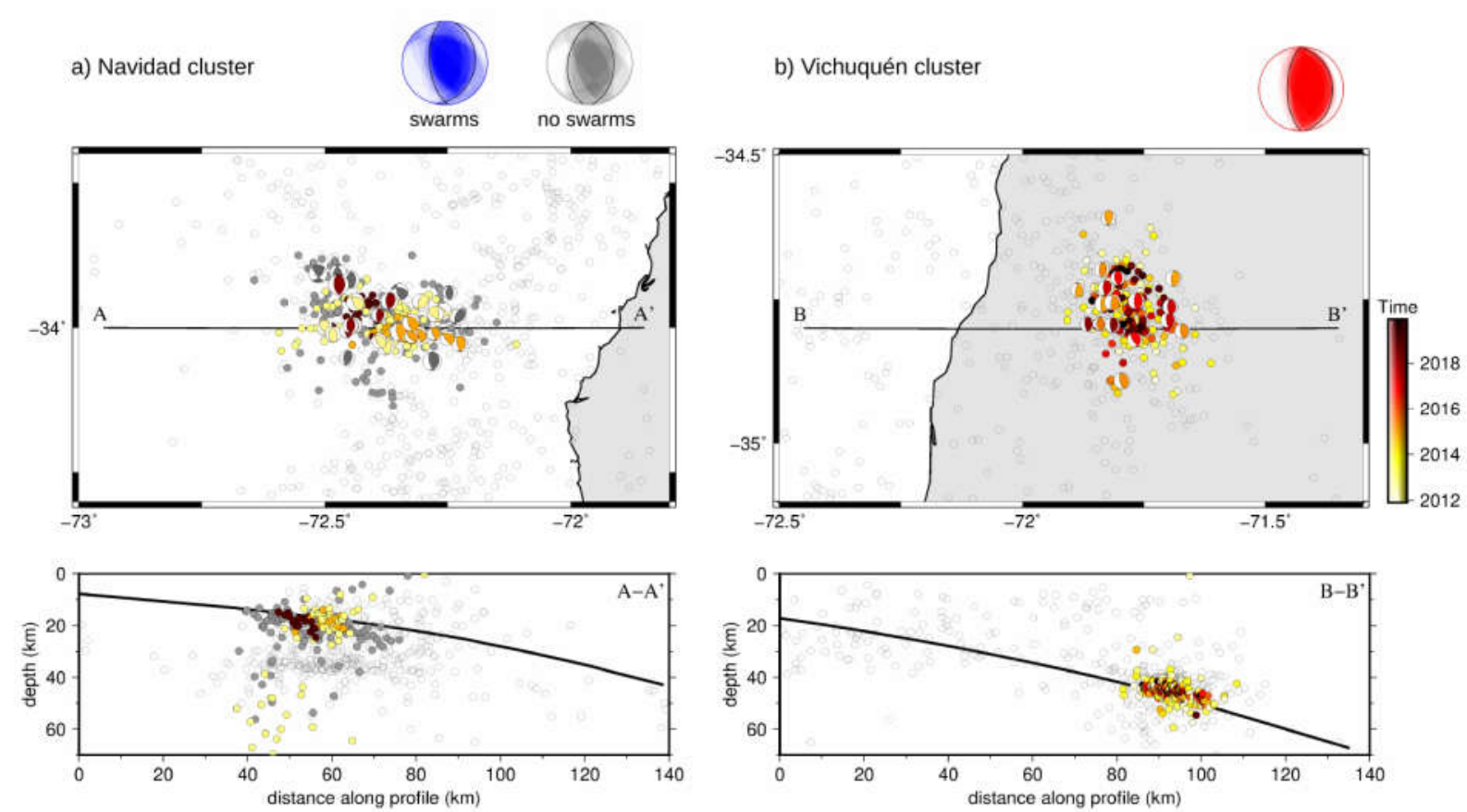

Figure 6. Results of the HypoDD 3D relocation and DC moment tensor inversion for the Navidad (a) and Vichuquén (b) clusters, including a map view of focal mechanisms results and relocated events, and vertical cross sections using the slab1.0 (Hayes et al. 2012); colors correspond to time scale 2012-2020. The focal spheres at the top indicate the distribution of focal mechanisms, and thick line the median mechanism. Navidad swarm events mechanisms (blue) have a different median mechanism than inter-swarm ones (gray focal mechanism and dots). At Vichuquén, mechanisms are more homogeneous, and fit with thrust failure at the plate interface. 


\section{Figure 7}

a) Similarity matrices
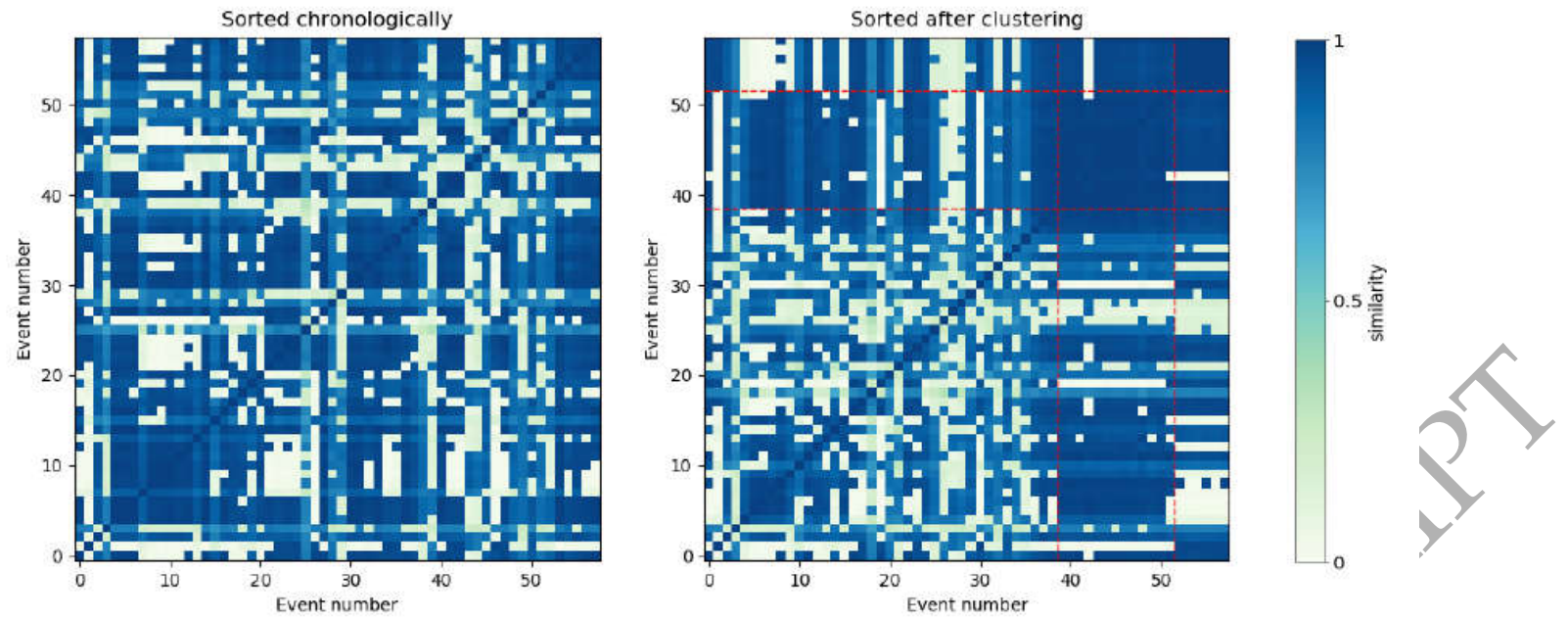

b)

Similarity matrices
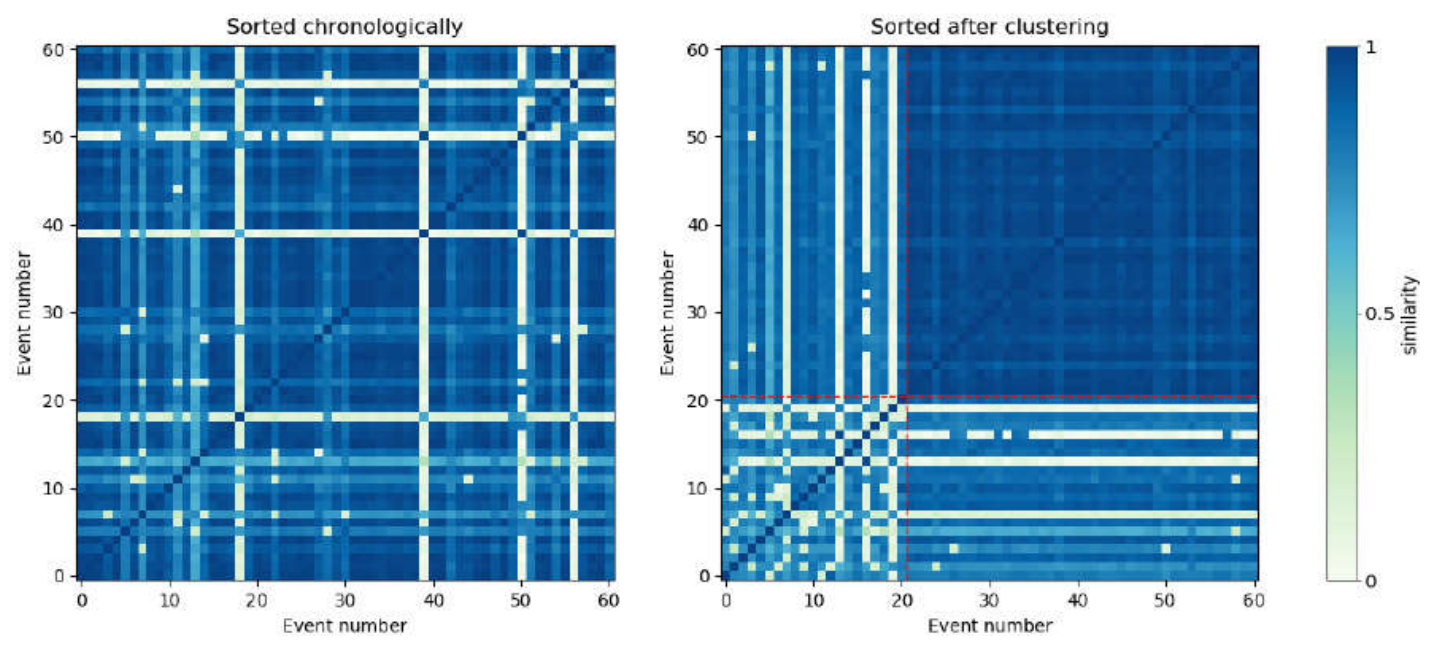

Figure 7. Similarity matrices show waveform similarities before (left) and after clustering (right) in the GO05 station in the Navidad cluster (a) and the Vichuquén cluster (b), band-pass filtered from $0.03-0.08 \mathrm{~Hz}$ and grouped with cross-correlation values greater than 0.9 . 


\section{Figure 8}

a)

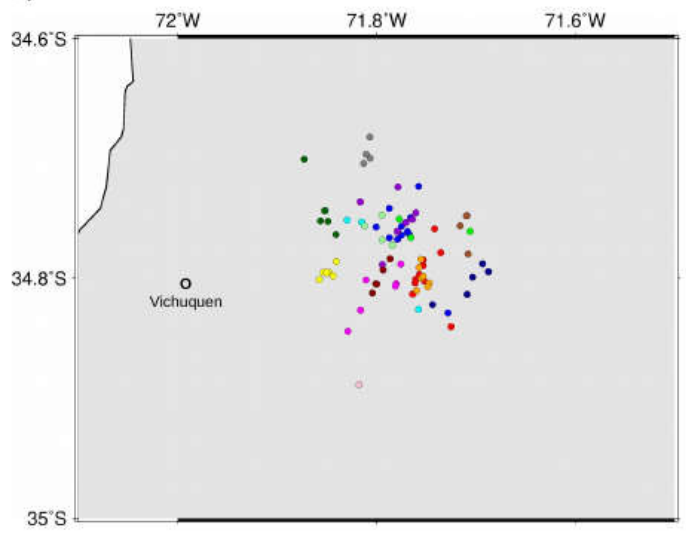

b)

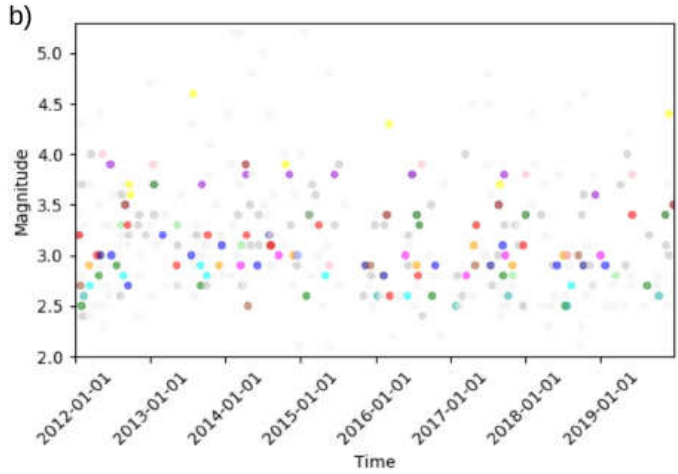

c) C.GO05 Z $-30 \mathrm{~km} \quad 1-4 \mathrm{~Hz}$
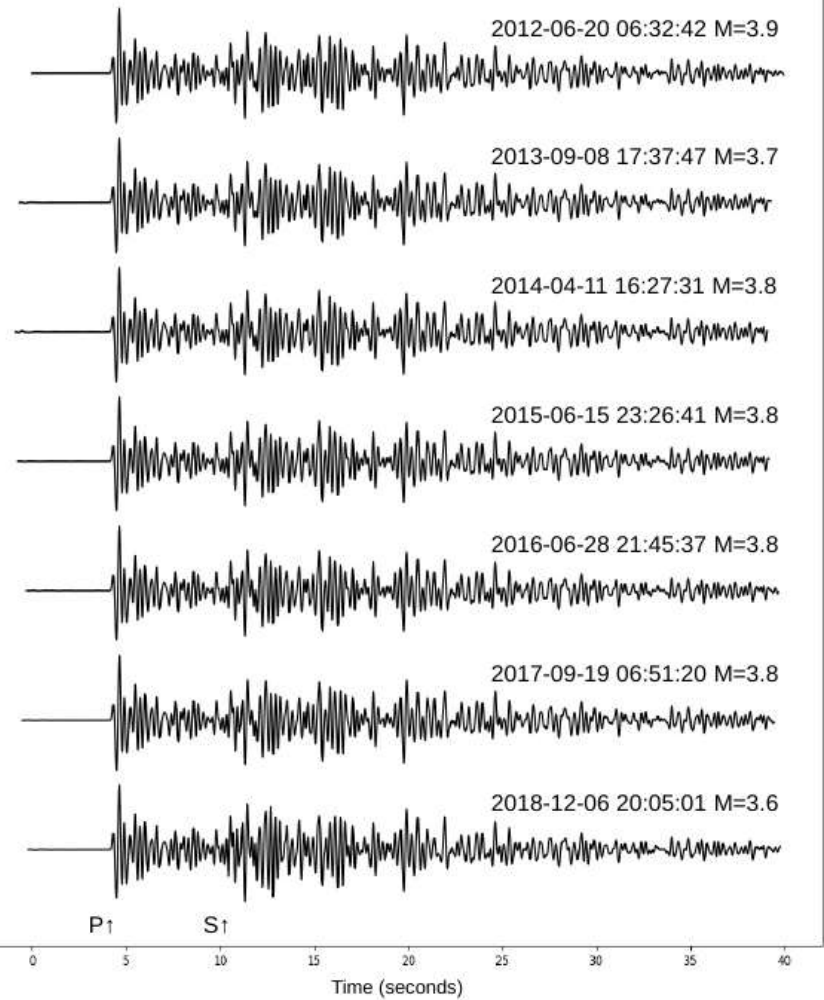

Figure 8. a) Locations of the families of repeaters, where colors refers to the different families in Tab. 3. b) Temporal evolution of all earthquakes in the repeater families (color-coded as in panel a). c) Example of 1-4 Hz bandpass-filtered waveforms of repeaters in the Vichuquén cluster in GO05 station, the normalized waveform observed in one of the largest family of repeaters, extracted a $40 \mathrm{~s}$ time window of the raw seismogram for the vertical component starting at the origin time. 
Figure 9

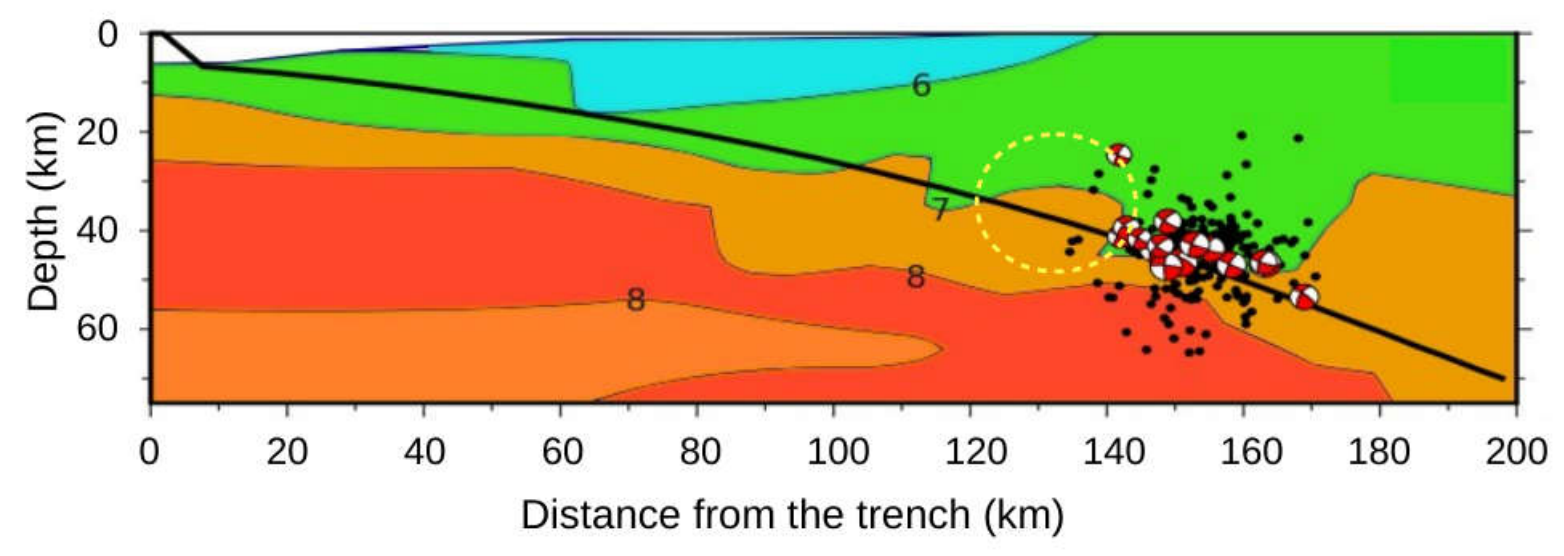

Figure 9. Cross section for the Vichuquén cluster with color-coded 3D P-wave velocity model calculated by Hicks et al. (2012) and contour lines labeled with P velocity in $\mathrm{km} / \mathrm{s}$. The cross section is from section AA' (from 73.2W,34.2S to 70.7W,35.0S) by Hicks et al. (2012). The dashed yellow circle indicates a smaller high-velocity anomaly in the Pichilemu region $\sim 135 \mathrm{~km}$ from the trench, along the thrust interface characterized by Hicks (2012). Black dots and focal mechanisms are from the Vichuquén cluster as in Fig. 6b. The seismic activity concentrates downdip of the Pwave anomaly crossing the slab interface. 


\section{Tables and table captions}

Table 1. Summary of the seismicity at the Navidad and Vichuquén cluster for the period 20002020.

Cluster name $\quad \mathrm{N}^{\circ}$ events $\quad$ Mean latitude Mean longitude $\quad$ Mean Depth $\quad$ Max. $\mathrm{M}_{\mathrm{L}}$

\begin{tabular}{cccccc} 
Navidad & 578 & $-34.00 \pm 0.05^{\circ}$ & $-72.35 \pm 0.10^{\circ}$ & $32.5 \pm 6.1 \mathrm{~km}$ & 5.9 \\
\hline Vichuquén & 830 & $-34.77 \pm 0.05^{\circ}$ & $-71.79 \pm 0.07^{\circ}$ & $41.9 \pm 5.5 \mathrm{~km}$ & 5.7
\end{tabular}

Table 2. Information for bursts of high rate seismicity. Swarms episodes (skewness below 8) are plotted with green background, mainsock-aftershock sequences (skewness above 8) with yellow background.

\begin{tabular}{cccccccc}
\hline Name & $\begin{array}{c}\text { Starting time } \\
\text { (d.m.y) }\end{array}$ & $\mathrm{N}^{\circ}$ events & $\begin{array}{c}\text { Duration } \\
\text { (days) }\end{array}$ & Skew & $\begin{array}{c}\text { Mag max } \\
\left(\mathrm{M}_{\mathrm{L}}\right)\end{array}$ & $\begin{array}{c}\text { Cum Mo } \\
(\mathrm{Nm})\end{array}$ \\
\hline Navidad 1 & 08.12 .2001 & 8 & 2 & 3.1 & & 4.2 & $9.6 \mathrm{e}+15$ \\
\hline Navidad 2 & 02.03 .2002 & 8 & 2 & -1.2 & 4.0 & $3.9 \mathrm{e}+15$ \\
\hline Navidad 3 & 07.09 .2004 & 21 & 3 & 1.7 & 5.3 & $3.1 \mathrm{e}+17$ \\
\hline Navidad 4 & 29.06 .2011 & 10 & 3 & 1.9 & & 4.3 & $6.2 \mathrm{e}+15$ \\
\hline Navidad 5.1 & 10.10 .2012 & 13 & 4 & 0.6 & 4.4 & $1.3 \mathrm{e}+16$ \\
\hline Navidad 5.2 & 11.11 .2012 & 16 & 2 & 6.5 & & 4.7 & $2.9 \mathrm{e}+16$ \\
\hline Navidad 5.3 & 19.11 .2012 & 26 & 5 & -1.5 & 5.2 & $1.1 \mathrm{e}+17$ \\
\hline Navidad 6 & 18.02 .2013 & 16 & 6 & 24.9 & 5.4 & $1.6 \mathrm{e}+17$ \\
\hline Navidad 7 & 19.10 .2014 & 14 & 7 & -8.8 & 5.0 & $6.5 \mathrm{e}+16$ \\
\hline Navidad 8 & 01.12 .2018 & 19 & 4 & 4.2 & 5.2 & $9.6 \mathrm{e}+16$ \\
\hline
\end{tabular}


Table 3. Detailed information on the Vichuquén repeating earthquakes sequences, the colours are according to Fig. 8. Slip rate 1 correspond to the result from crack model relation and the Slip rate 2 correspond to the result from empirical relation.

\begin{tabular}{lcccccc}
$\begin{array}{l}\text { Family } \\
\text { repeaters }\end{array}$ & $\begin{array}{c}\text { Number of } \\
\text { events }\end{array}$ & $\mathrm{M}_{\mathrm{L}}$ range & Cum Mo $[\mathrm{Nm}]$ & $\begin{array}{c}\text { Duration } \\
(\mathrm{yr})\end{array}$ & $\begin{array}{c}\text { Slip rate } 1 \\
(\mathrm{~cm} / \mathrm{yr})\end{array}$ & $\begin{array}{c}\text { Slip rate 2 } \\
(\mathrm{cm} / \mathrm{yr})\end{array}$ \\
\hline , red & 14 & $2.6-3.4$ & $9.84 \mathrm{e}+14$ & 8 & 2.8 & 3.0 \\
\hline 3, blue & 12 & $2.7-3.2$ & $4.58 \mathrm{e}+14$ & 8 & 2.0 & 2.6 \\
4 , vioen & 9 & $2.5-2.9$ & $1.30 \mathrm{e}+14$ & 8 & 1.1 & 2.1 \\
\hline 5, yellow & 8 & $3.6-3.9$ & $4.81 \mathrm{e}+15$ & 7 & 3.7 & 4.5 \\
\hline 6 , orange & 8 & $2.8-4.6$ & $2.07 \mathrm{e}+16$ & 8 & 4.2 & 5.0 \\
\hline 7 , cyan & 7 & $2.9-3.1$ & $2.48 \mathrm{e}+14$ & 7 & 1.3 & 2.7 \\
8, brown & 7 & $2.6-2.9$ & $1.26 \mathrm{e}+14$ & 7 & 1.1 & 2.4 \\
\hline 9, turquoise & 6 & $2.5-3.1$ & $1.74 \mathrm{e}+14$ & 7 & 1.0 & 2.5 \\
\hline 10, pink & 6 & $2.5-2.6$ & $5.41 \mathrm{e}+13$ & 8 & 0.7 & 1.8 \\
\hline 11, dark green & 6 & $2.9-4.0$ & $4.33 \mathrm{e}+15$ & 8 & 2.4 & 3.8 \\
\hline 12, magenta & 6 & $3.3-3.7$ & $1.19 \mathrm{e}+15$ & 7 & 1.9 & 3.5 \\
\hline 13 , dark blue & 5 & $2.8-3.0$ & $2.07 \mathrm{e}+14$ & 6 & 1.3 & 3.0 \\
\hline 14, light green & 5 & $2.8-3.3$ & $3.20 \mathrm{e}+14$ & 8 & 1.0 & 2.8 \\
\hline 15, dark red & 5 & $3.4-3.9$ & $1.72 \mathrm{e}+15$ & 8 & 1.6 & 3.3 \\
\hline 16 silver & 5 & $3.1-3.3$ & $4.39 \mathrm{e}+14$ & 8 & 1.1 & 2.6 \\
\hline
\end{tabular}

